УДК 556.3(571.1)

\title{
ЭВОЛЮЦИЯ ГИДРОГЕОХИМИЧЕСКОГО ПОЛЯ СЕВЕРНЫХ И АРКТИЧЕСКИХ РАЙОНОВ ЗАПАДНО-СИБИРСКОГО ОСАДОЧНОГО БАССЕЙНА В МЕЗОЗОЕ
}

\author{
Новиков Дмитрий Анатольевич ${ }^{12,}$ \\ NovikovDA@ipgg.sbras.ru \\ Черных Анатолий Витальевич',
ChernykhAV@ipgg.sbras.ru
}

Садыкова Яна Владиславовна',

SadykovaYV@ipgg.sbras.ru

\section{Дульцев Федор Федорович', \\ DultsevFF@ipgg.sbras.ru}

\author{
Хилько Василина Александровна', \\ KhilkoVA@ipgg.sbras.ru \\ Юрчик Ирина Ивановна', \\ Yurchikl|@ipgg.sbras.ru \\ 1 Институт нефтегазовой геологии и геофизики им. А.А. Трофимука СО РАН, \\ Россия, 630090, г. Новосибирск, пр. Академика Коптюга, 3/6. \\ ${ }^{2}$ Новосибирский национальный исследовательский государственный университет, \\ Россия, 630090, г. Новосибирск, ул. Пирогова, 1.
}

Актуальность исследования состоит в выявлении фундаментальной роли палеогидрогеологических факторов в эволюции гидрогеохимического поля северных и арктических районов Западно-Сибирского осадочного бассейна в мезозойскую эру. Впервые предложен механизм, объясняющий их вклад в формирование гидрогеохимических аномалий в оксфордском резервуаре (верхнеюрском водоносном комплексе) изучаемого региона, где широко развита гидрогеохимическая инверсия.

Цель: выявить особенности состава сингенетичных вод, захораниваемых одновременно с осадком на элизионных и инфильтрационных этапах развития осадочного бассейна на основе установленной цикличности гидрогеологической истории северных и арктических районов Западно-Сибирского осадочного бассейна; выполнить сравнительных анализ состава современных и сингенетичных вод и установить природу гидрогеохимических аномалий.

Методы. Использованы методические приемы А.А. Карцева, С.Б. Вагина, Е.А. Баскова и других исследователей по палеогидрогеологическим реконструкциям осадочных бассейнов, выполнена периодизация гидрогеологической истории с выделением основных гидрогеологических циклов и инфильтрационных и элизионных этапов. На основе методики восстановления солевого состава вод древних морских и озерно-аллювиальных бассейнов, палеогеографических карт на юрский и меловой периоды, составленных сотрудниками ИНГГ СО РАН, информационного банка данных лаборатории гидрогеологии осадочных бассейнов Сибири ИНГГ СО РАН по арктическим районам Западно-Сибирского осадочного бассейна проведены палеогидрогеохимические реконструкции юрско-мелового разреза.

Результаты. Приводятся результаты палеогидрогеологических реконструкций северных и арктических районов Западно-Сибирского осадочного бассейна. Установлено, что в гидрогеологическом разрезе исследуемого региона доминируют седиментогенные воды, в некоторых случаях разбавленные инфильтрогенными, проникшими при регрессии морского бассейна. Сравнительный анализ захороненных сингенетичных вод оксфордского бассейна и данных по современной гидрогеохимии подземных вод выявил ряд отрицательных и положительных аномалий. Отрицательные аномалии закономерно трассируют границу глинизации оксфордского регионального резервуара и связаны с развитием процессов элизионного водообмена. Геостатическая (литостатическая) водонапорная система на глубинах 2×2,5 км переходит в термодегидратационную, что сопровождается аномально высокими пластовыми давлениями и появлением в водонапорной системе пресных химически-связанных вод. Большинство положительных аномалий приурочены к структурам Южно-Надымской и Предъенисейской мегамоноклиз, где широко проявлены процессы вертикальной разгрузки подземных вод нижне-среднеюрского и палеозойского водоносных комплексов в зонах тектонических нарушений. Системе «вода-порода-газ-органическое вещество» принадлежит ключевая роль в процессах формирования химического состава подземных вод нефтегазоносных отложений.

\section{Ключевые слова:}

Гидрогеологический цикл, палеогидрогеохимия, инфильтрация, элизия, гидрогеохимия, оксфордский региональный резервуар, Западная Сибирь, Арктика.

\section{Введение}

Зарождение палеогидрогеологических исследований осадочных бассейнов связано с именем П.Н. Чирвинского [1]. В дальнейшем развитием этого научного направления занимались выдающиеся исследователи: А.М. Никаноров, Л.А. Абукова, К.И. Маков, А.М. Овчинников, Е.А. Басков, Е.В. Пиннекер, Е.А. Барс, Я.А. Ходжакулиев, 
Л.Г. Борзасекова, А.Н. Семихатов, Р.И. Быков, Г.П. Якобсон, С.Б. Вагин, М.А. Гатальский, А.А. Карцев, А.А. Розин, А.Д. Назаров, В.М. Матусевич, Е.И. Сорокова, В.П. Шугрин и многие другие [2-8]. Активное развитие палеогидрогеологических исследований в странах Европы, Америки, Азии и Ближнего Востока обязано появлению изотопных методов исследований, изучению газово-жидких включений в минералах и т. д. [9-50]. Но даже несмотря на большие достижения в палеогидрогеологической области, многие вопросы до сих пор остаются недостаточно изученными. Для решения вопросов о формировании состава подземных вод, их генезиса, типа вертикальной гидрогеохимической зональности, а также протекании процессов нефтегазообразования и нефтегазонакопления необходимо привлекать комплекс данных из области гидрогеологии, литологии, стратиграфии, тектоники и т. д. [51, 52].

Исследования арктических регионов Западной Сибири началось еще в 30-е гг. ХХ в. Н.А. Гедройцем, Т.К. Емельянцевым, А.Я. Кремсом, Н.Н. Ростовцевым, Г.Е. Рябухиным, В.Н. Саксом, И.Н. Стрижовым, Н.Н. Тихоновичем и многими другими [53]. Начиная с 1950-х гг. основные геологоразведочные работы в пределах Западно-Сибирской нефтегазоносной провинции (ЗСНП) проводились в северных районах, где в 1962 г. было открыто первое газовое месторождение - Тазовское. Значительный вклад в изучение арктической части ЗСНП внесли: И.С. Грамберг, В.Е. Хаин, Г.Д. Гинсбург, Д.Б. Тальвирский, В.В. Гребенюк, Д.С. Сороков, А.И. Данюшевская, В.Г. Сибгатулин, В.А. Захаров, В.Н. Сакс, М.К. Калинко, И.Д. Полякова, Г.Н. Карцева, Л.Л. Кузнецов, А.Э. Конторович, В.Д. Накоряков и другие. На данный момент можно с уверенностью утверждать, что ресурсы углеводородов в российской Арктике уникальны по объемам и разнообразию и могут достигать 70,6 млрд т нефти, 202,2 трлн $\mathrm{M}^{3}$ свободного газа, 5429,8 млрд м $^{3}$ попутного газа и 7703,2 млн т конденсата [54].

\section{Материалы и методы исследований}

Согласно А.А. Карцеву, С.Б. Вагину и Е.А. Баскову [3, 57], гидрогеологический цикл включает в себя два этапа. Первый этап - седиментационный (элизионный), в течение которого захораниваются одновременно с осадками сингенетичные седиментогенные воды. Второй - инфильтрационный этап, когда в осадочный бассейн проникают инфильтрационные воды, постепенно вытесняя и замещая седиментационные [3, 55].

В основе выделения элизионных и инфильтрационных циклов лежали данные о преимущественно морском и континентальном режиме осадконакопления соответственно, полученные при анализе палеогеографических карт и лито-фациальных схем $[56,57]$. Названия некоторым циклам давались по приуроченности к ярусам стратиграфической шкалы, ввиду несоответствия их границам эратем, систем или отделов). Значительное место в настоящем исследовании отводилось интерпретации каротажных диаграмм с целью выделения песчаников/алевролитов и глин/аргиллитов в разрезах глубоких скважин.

В данном исследовании основой для палеогидрогеохимических реконструкций послужили методика восстановления солевого состава вод древних бассейнов $[6,8,51]$, палеогеографические карты на юрский и меловой периоды, составленные сотрудниками ИНГГ СО РАН [56, 57], информационный банк данных лаборатории гидрогеологии осадочных бассейнов Сибири ИНГГ СО РАН по арктическим районам ЗСОБ, представленный результатами испытания более 4000 объектов 251 поисковой площади, включая данные полного химического анализа 5603 проб подземных вод.

\section{Результаты исследований и обсуждение}

Особенности гидрогеохимии подземных вод

В пределах отложений юры и мела арктических районов ЗСОБ установлены воды с минерализацией от 2 до 64 г/дм ${ }^{3}$ разных химических типов, при доминировании хлоридного, хлоридно-гидрокарбонатного и гидрокарбонатно-хлоридного натриевого типов (по С.А. Щукареву). По мере роста величины минерализации происходит закономерное увеличение содержаний основных макрокомпонентов ( $\mathrm{Na}, \mathrm{K}, \mathrm{Mg}, \mathrm{Ca}, \mathrm{Cl})$, а также микрокомпонентов: I, B, Br, $\mathrm{NH}_{4}$ и $\mathrm{Sr}$. Водоносные комплексы (нижне-среднеюрский, верхнеюрский, неокомский и апт-альб-сеноманский) характеризуются рядом гидрогеохимических особенностей, обусловленных гидрогеологической историей и вертикальной миграцией рассолов из фундамента в осадочный чехол.

Подземные воды верхнеюрских отложений имеют разный химический состав, среди них доминируют $\mathrm{Cl} \mathrm{Na}, \mathrm{HCO}_{3}-\mathrm{Cl} \mathrm{Na}$ и $\mathrm{Cl}-\mathrm{HCO}_{3} \mathrm{Na}$ с величиной общей минерализации от 5,0 до 63,3 г/дм ${ }^{3}$ [58-64]. По мере роста минерализации происходит смена химического типа вод с гидрокарбонатнохлоридного натриевого на хлоридный натриевый (рис. 1). Отмечается уменьшение разнообразия вод по химическому составу с увеличением их минерализации.

Так, при минерализации вод 2-5 г/дм³ выделяется семь химических типов подземных вод, при 10-15 г/дм ${ }^{3}$ - пять, при 20-25 г/дм ${ }^{3}$ - два типа, при значении более $25 \mathrm{r} /$ дм$^{3}$ только один - хлоридный натриевый тип. Величина фоновой минерализации подземных вод верхнеюрского водоносного комплекса в изучаемом регионе составляет 19,9 г/дм³ . В пределах Северного и Нижневартовского сводов, Восточно-Пурской мегамоноклинали и Южно-Надымской мегамоноклизы распространены воды с минерализацией более 25 г/дм ${ }^{3}$. Наиболее высокие значения зонального гидрогеохимического фона выявлены для структур Северного свода, где величина общей минерализации фоновых пластовых вод достигает 33,5 г/дм³ . Значения 


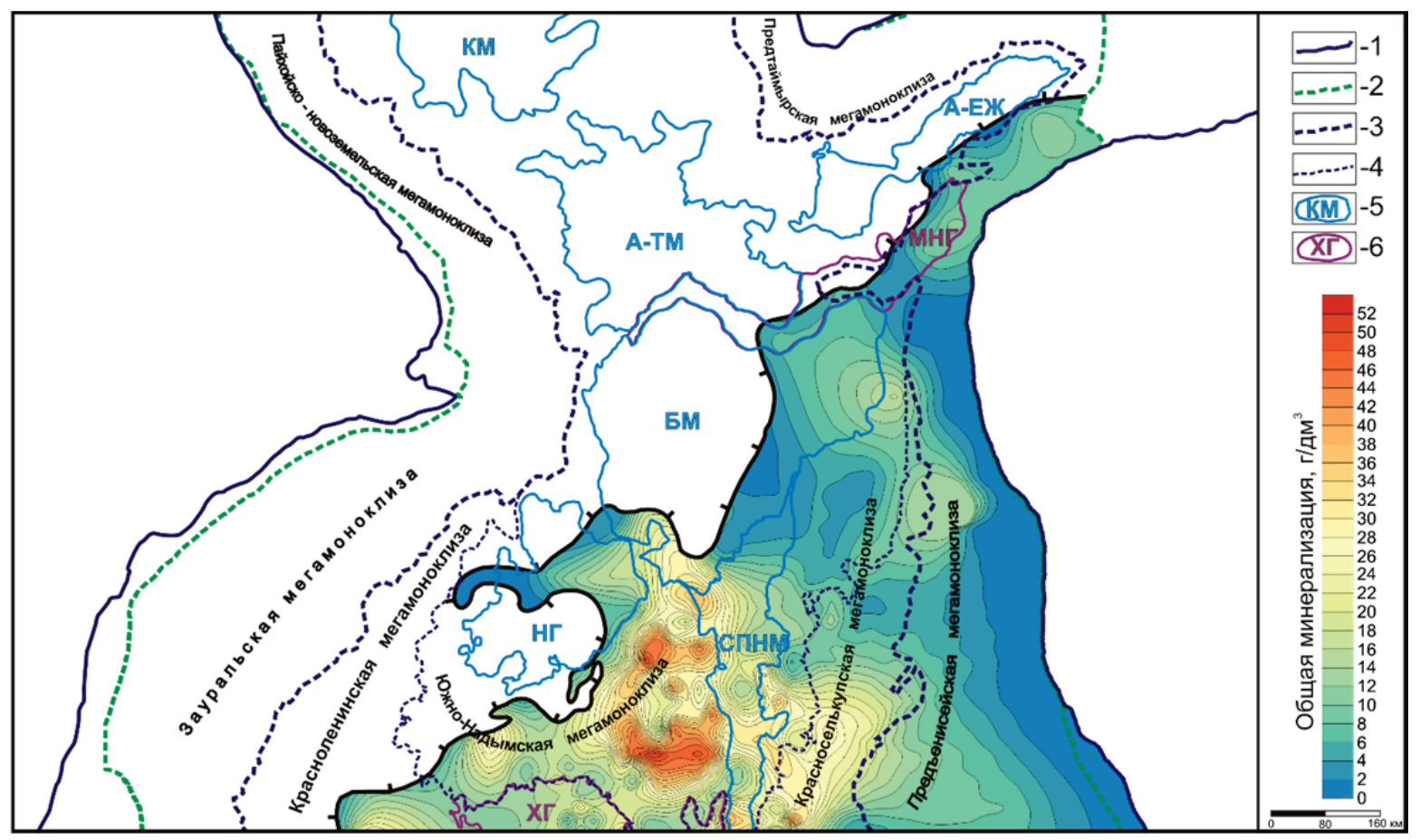

Pис. 1. Карта общей минерализации подзелных вод верхнеюрского водоносного колплекса северных и арктических районов ЗСоБ. Границы: 1 - Западно-Сибирского осадочного бассейна; 2 - юрского осадочного бассейна; 3 - Внутренней области и Внешнего пояса; 4 - Ялало-Карской депрессии; Положительные тектонические элеленты- структуры 0 порядка: КM - Карская мегасинеклиза, А-ТМ - Антипаютинско-Тадебеяхинская мегасинеклиза, А-ЕЖ - Агапско-Енисейский желоб, БМ - Больщехетская мегасинеклиза, НГ - Надылская гемисинеклиза, СПНМ - Среднепурский наклонный мегажелоб; Отрицательные тектонические элементы - структуры 0 порядка: МНГ-Мессояхская наклонная гряда, ХГ-Хантейская гелисинеклиза

Fig. 1. Map of the total groundwater salinity of the Upper Jurassic aquiferous complex of the northern and arctic regions of the WSSB. Borders: 1 - West Siberian sedimentary basin; 2 - Jurassic sedimentary basin; 3 - Inner region and Outer belt; 4 - Yamalo-Kara depression; Positive tectonic elements - structures of 0 order: KM - Kara megasyneclise, A-TM - Antipayutinsko-Tadebeyakha megasyneclise, A-EЖ - Agapsko-Yenisei trough, BM - Bolshekhetskaya megasinekliza, HГ - Nadym hemisineclisy, CПHM - Srednepursky inclined megatrough Negative tectonic elements - structures of order 0: $M H \Gamma$ - Messoyakhskaya oblique ridge, $\mathrm{X} \Gamma$ - Hantei hemisyneclise

величины общей минерализации уменьшаются до 5-10 г/дм ${ }^{3}$ в направлении к прибортовым зонам бассейна (рис. 1) [58, 59, 61].

С увеличением минерализации подземных вод происходит закономерное снижение величины основных генетических коэффициентов. Так, например, значения коэффициента метаморфизации $\mathrm{rNa} / \mathrm{rCl}$ снижаются с 2,20-3,09 при солености вод 5-9 г/дм ${ }^{3}$ до 0,85-0,88 при минерализации более 25 г/дм ${ }^{3}$ [65]. Уменьшение величины в два и более раза характерно также для всех других генетических коэффициентов. Значения $\mathrm{Cl} / \mathrm{Br}$ коэффициента понижаются с 400 при минерализации 5,1 г/дм ${ }^{3}$ до 211-275 при солености более 25 г/дм ${ }^{3}$, $\mathrm{B} / \mathrm{Br}$ с 3,09 до 0,07-0,17 соответственно [59]. Установлено, что поведение $\mathrm{rNa} /(\mathrm{rCa}+\mathrm{rMg})$ и $\mathrm{Br} / \mathrm{I}$ несколько отличается от общих тенденций. У отношения $\mathrm{rNa} /(\mathrm{rCa}+\mathrm{rMg})$ максимальное значение составляет 50 при минерализации подземных вод $5-10$ г/дм ${ }^{3}$, затем происходит его закономерное снижение до установленной ранее величины 5 у наиболее соленых вод. Отношение $\mathrm{Br} / \mathrm{I}$ нарастает до 8,9 в водах с соленостью $15-20$ г/дм ${ }^{3}$ и затем также снижается. Наиболее широкий интервал ва- риации значений наблюдается у отношения $\mathrm{HCO}_{3} / \mathrm{Cl}$ (от 0,04 до 1,59).

\section{Палеогидрогеологические реконструкции}

Периодизация гидрогеологической истории позволила выделить три гидрогеологических цикла в триасово-меловое время: индско-синемюрский, плинсбахско-сеноманский и туронско-серраваллийский (рис. 2). Начало формирования осадочного чехла связано с образованием туринской серии (вулканогенно-осадочной) в раннем триасе. Преобладающими обстановками осадконакопления являлись аллювиальная и аккумулятивная равнины, которые были обрамлены возвышенными территориями на западе и востоке. Новая земля и Таймырские горы служили источниками сноса в северной части. В среднем триасе в исследуемом регионе доминировали денудационные процессы и процессы инфильтрации атмосферных вод.

В плинсбахе началась трансгрессия моря. Морской бассейн был мелководным (до 25 м) с опресненными водами, Гыданский и Ямальский полуострова были представлены зоной мелководья, где вследствие неустойчивого морского режима и реч- 
ного стока происходили значительные колебания солености вод от 2 до $15 \mathrm{r} /$ дм $^{3}$, на что указывает бедность органического мира (аммониты и брахиоподы немногочисленны, при высоком содержании пелеципод, характерных для морских побережий), а также поглощенный комплекс глин (низкие содержания $\mathrm{K}$ и $\mathrm{Mg}$ и высокие - $\mathrm{Na}$ и $\mathrm{Ca}$ ) $[4,66]$. Совместно с ними захоронялись преимущественно $\mathrm{Cl} \mathrm{Na}$ воды с высокими содержаниями $\mathrm{HCO}_{3}^{-}$и $\mathrm{Ca}^{2+}$ с величиной общей минерализации $2-5$ г/дм ${ }^{3}$. В южном направлении происходила смена от прибрежно-морских к континентальным обстановкам и преобладали процессы инфильтрации атмосферных осадков. Прибортовые районы бассейна представляли собой возвышенную равнину. Таймырская, Новоземельская, Уральская и Средне-Сибирская возвышенности являлись источниками сноса и внешними областями инфильтрационного питания, в пределах которых захоранивались $\mathrm{HCO}_{3} \mathrm{Ca}$ воды с минерализацией, не превышающей 0,5 г/дм³. В тоарское время произошла крупнейшая в ранней и средней юре трансгрессия. Существенно расширилась область морского осадконакопления и произошло углубление морского

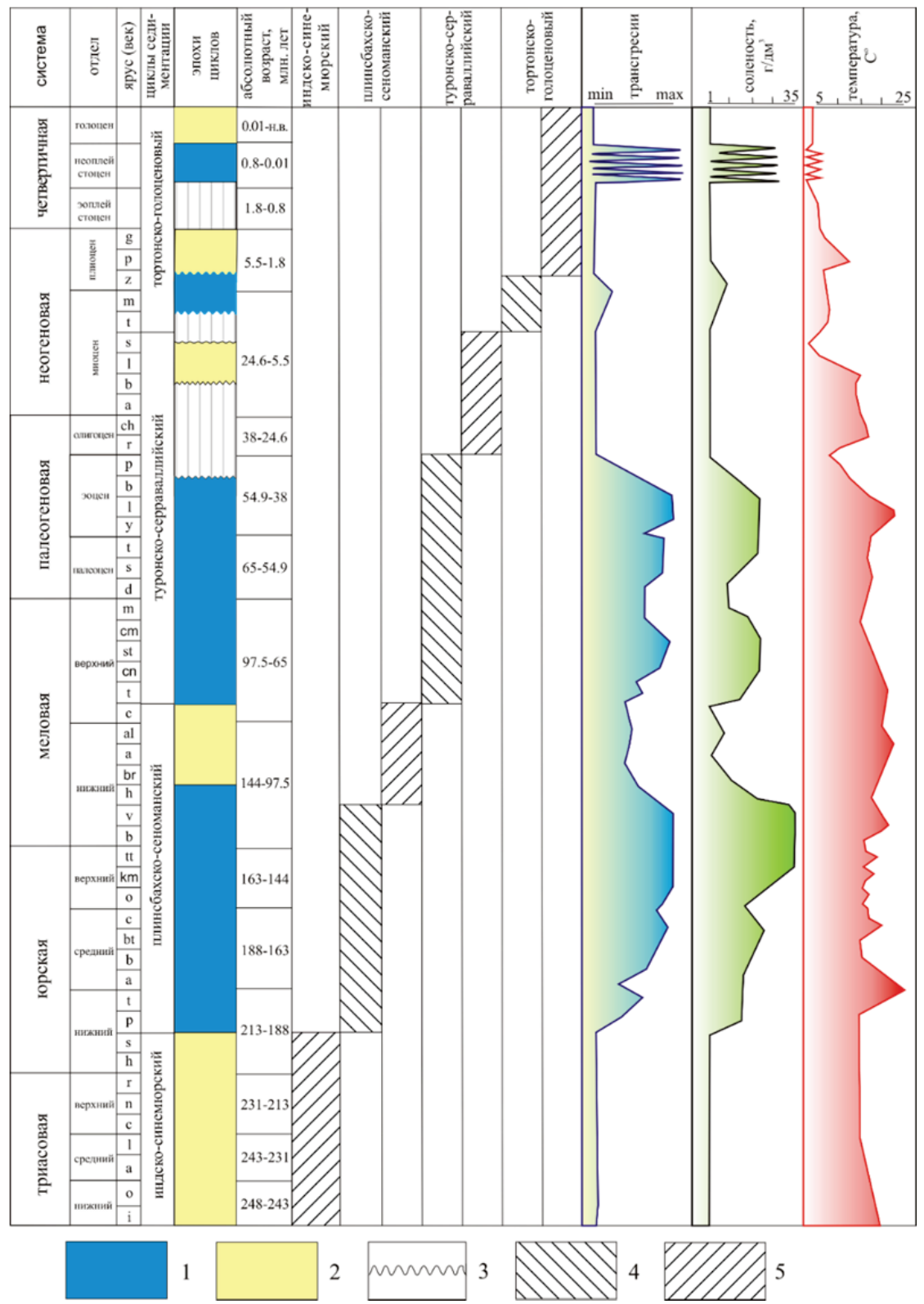

Рис. 2. Схема периодизации гидрогеологической истории и характеристика палеосреды северной части Западно-Сибирского мегабассейна. Условные обозначения: ииклы седилентации: 1 - эпоха трансгрессии моря, 2 - регрессии моря; 3- зоны размыва пластов; гидрогеологический этап: 4 - элизионный; 5 - инфильтрационный

Fig. 2. Scheme of the hydrogeological history periodization and the characteristics of the paleoenvironment of the northern part of the West Siberian megabasin. Legend: sedimentation cycles: 1 - transgression of the sea, 2 - regression of the sea; 3 - abrasion zone; hydrogeological stage: 4 - elision; 5 - infiltration 
бассейна. В центральной части бассейна (Карская, Антипаютинско-Тадебияхинская и Большехетская мегасинеклизы и Агапско-Енисейский желоб) глубины моря достигали $100 \mathrm{~m}$, а соленость сингенетичных вод могла достигать 30 г/дм ${ }^{3}$. В глубоководной части накапливались илы китербютской свиты, которая впоследствии стала одной из нефтематеринских толщ. Находки морской фауны (ростры белемнитов, двустворки, фораминиферы) подтверждают установление нормальноморского режима седиментации в регионе [66].

Низменная аккумулятивная равнина окаймляла тонкой полосой возвышенные денудационные равнины вдоль западного и восточного берегов бассейна и в целом имела те же очертания, что и в плинсбахе. В позднем тоаре - раннем аалене на северо-западе, за счет расширения зоны мелководья (до 25 м), сократилась площадь морского осадконакопления (25-100 м). В составе осадков в центральной части бассейна по-прежнему доминировала глинистая составляющая, а к бортам фиксировалось увеличение доли грубообломочной составляющей и появление пластов песчаников. Прибрежная и денудационная равнины также оставались в прежних границах. Во второй половине аалена и начале байоса происходили кратковременные повышения уровня моря и незначительные изменения климата, что не оказало влияния на гидрогеологическую историю.

В батском веке продолжилось прогибание арктических регионов Западной Сибири и увеличились периоды трансгрессии, но положение зон морской седиментации практически не изменилось. На севере региона зона мелководья расширилась за счет затопления низменной аккумулятивной равнины, окаймляющей борта бассейна. Продолжение обширной морской трансгрессии в келловейский век повлекло дальнейшее углубление морского бассейна, который занимал практически всю площадь Западно-Сибирской геосинеклизы, за исключением ее южных окраин. В это время в глубоководно-морских условиях накопились мощные глинистые толщи гольчихинской и яковлевской свит, которые являются региональными флюидоупорами. Глубина моря в наиболее погруженной части достигала 400 м. Соленость вод бассейна достигала 35 г/ дм $^{3}$. В прибрежных зонах накапливались глинистые осадки [66], палеосоленость вод составляла 30-35 г/ дм $^{3}$ и возрастала роль магния в составе захоранивающихся вод. Небольшую по площади территорию занимала мелководная зона с глубиной моря до 25 м, шириной до $80 \mathrm{kм}$, где формировались разнофациальные осадки из-за смены континентальных и прибрежно-морских обстановок, и захоранивались сингенетичные $\mathrm{Cl} \mathrm{Na}$ воды с минерализацией $5-15$ г/дм ${ }^{3}$ и высоким содержание $\mathrm{HCO}_{3}^{-}$и $\mathrm{Ca}^{2+}$. Площадь зон континентального осадконакопления значительно сократилась, и остались только крутые берега бассейна, представленные возвышенной равниной и горами, являющимися внешней областью питания.
На границе оксфордского и келловейского веков трансгрессия сменилась регрессией, достигшей своего пика в середине оксфорда. Из-за обмеления бассейна в его центральной и южной частях начали накапливаться мощные песчаные пласты - оксфордский региональный резервуар (горизонт $\mathrm{Ю}_{1}$ ), соответствующий проницаемой части верхнеюрского водоносного комплекса. На севере преобладали морские условия и образовывались преимущественно глинистые осадки гольчихинской свиты, богатые органическим веществом, с многочисленными остатками разнообразной морской фауны. Практически весь исследуемый регион был представлен зоной с глубинами 25-100 м, а соленость захораниваемых вод была близка к 20 г/дм ${ }^{3}$ (рис. 3). В позднеоксфордское-кимериджское время, из-за самой длительной юрской трансгрессии, расширились границы морского осадконакопления, а глубина бассейна на большей части территории стала достигать 200 м [66]. В волжское время (титон-ранний берриас) бассейн продолжал интенсивно прогибаться и трансгрессия достигла своего максимума в середине века. В регионе доминировал семиаридный климат, в континентальных обстановках преобладало химическое выветривание, а на шельфе накапливались органогенные и глинистые породы. Глинистые осадки баженовской, гольчихинской, даниловской, тутлеймской и яновстанской свит, насыщенных органическим веществом (OB), кремнием и кальцием, образовывались при биогенном осадконакоплении из-за пенепленизации рельефа [66]. На конец волжского времени в арктических районах ЗСАБ сформировался глубоководный бассейн с признаками сероводородного заражения (рис. 4), где палеосоленость вод достигала 35 г/ дм³ $^{3}$ В пределах Большехетской и Карской мегасинеклиз глубоководные впадины достигали $400 \mathrm{~m}$, а минерализация вод вероятно достигала 38 г/дм³. На глубинах моря 100-200 м захоронялись талассогенные воды минерализацией до 20-30 г/дм³ . Также сократилась зона с глубинами моря 25-100 м, а море с глубинами до 25 м занимало незначительную площадь, ширина которой порой не превышала 10 км. В областях континентального осадконакопления захоранивались пресные атмогенные $\mathrm{HCO}_{3} \mathrm{Ca}$ воды с минерализацией до 1-2 г/дм³

В начале берриасского века при тектонических процессах, приведших к формированию горного рельефа и, как следствие, к преобладанию механического выветривания сформированных ранее пород. $K$ концу берриаса в регионе доминировало моpe с глубиной 200-400 м. Морской бассейн в глубоководных частях имел близкую к океанической палеосоленость из-за своей связи с бореальными морями. В следствие продолжавшейся в валанжинский век регрессии, взявшей свое начало в конце волжского времени, в бассейне, ставшем ассиметричным, увеличилась мелководная зона с глубинами до 25 м, а в прибрежной зоне захоронялись воды с доминированием в составе ионов $\mathrm{Cl}^{-}$и $\mathrm{Na}^{+}$при повышенном содержании $\mathrm{Ca}^{2+}$ и минерали- 


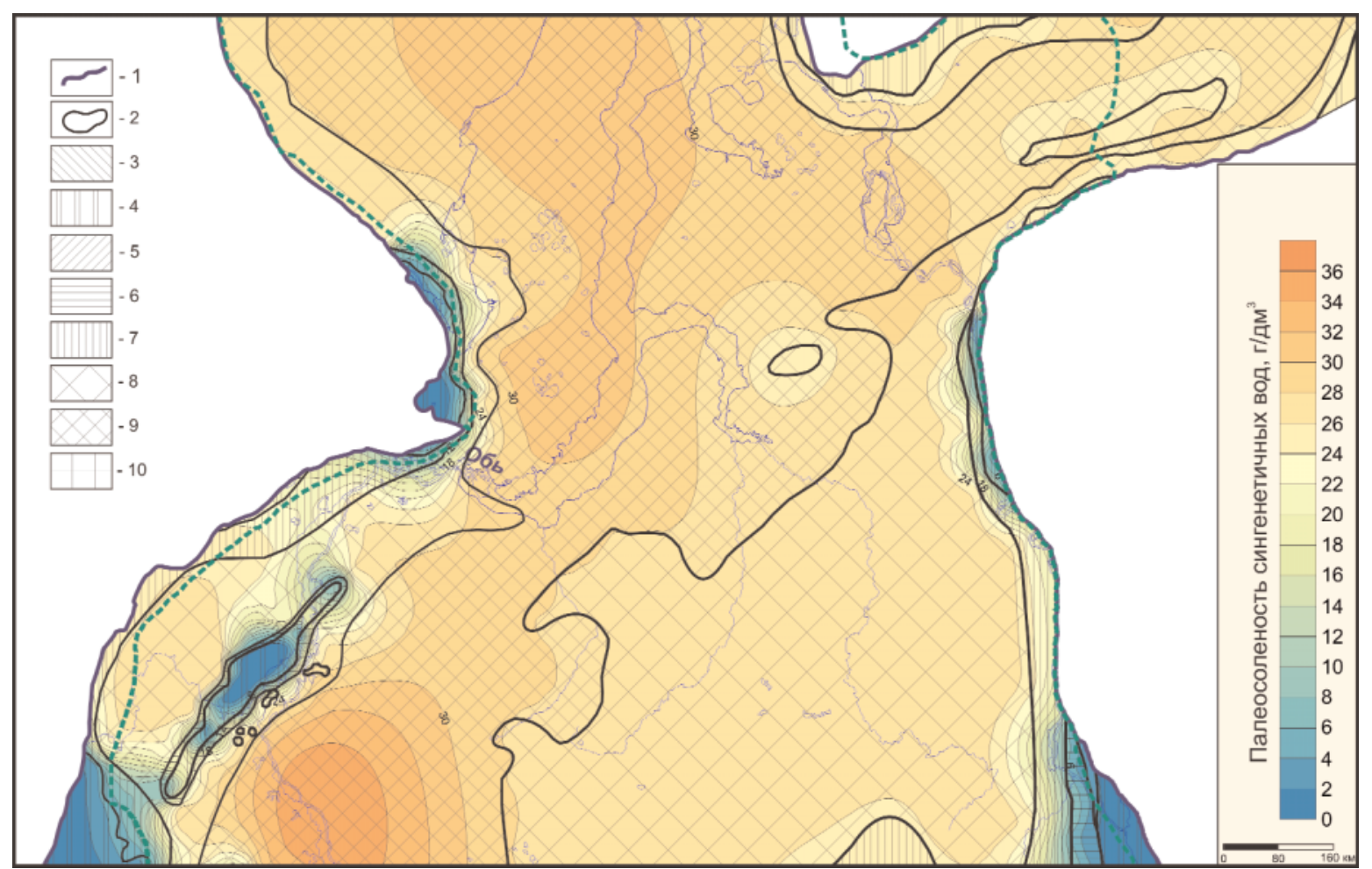

Рис. 3. Палеогидрогеохилическая карта на оксфордский век: 1 - граница юрского осадочного бассейна; 2 - граница палеогидрогеохили ческих зон: 3 - горы низкие, преобладают проиессы инфильтраиии пресных метеогенных вод с минерализацией до 0,5 г/д ${ }^{3}$ и с долинированиел ионов $\mathrm{HCO}_{3}^{-}$и $\mathrm{Ca}_{2+}^{2} ; 3$ - равнина возвышенная, пресные и солоноватые инфильтрогенные воды с линерализаци-

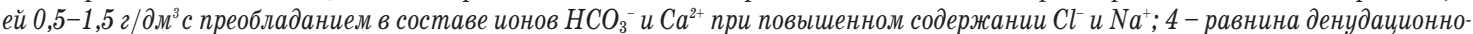

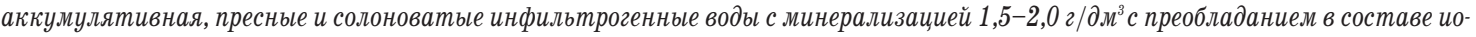
нов $\mathrm{HCO}_{3}^{-}$и $\mathrm{Ca}^{2+}$ при повышеннол содержании $\mathrm{Cl}^{-}$и $\mathrm{Na}^{+} ; 5$ - равнина низменнал аккулулятивнал, захоронение солоноватых во-

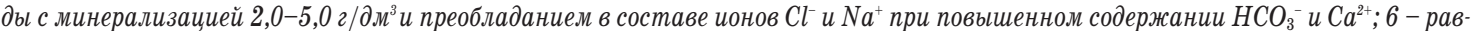

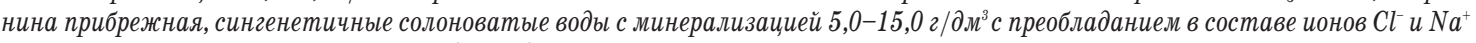
при повышенном содержании ионов $\mathrm{Mg}^{2+}$ и $\mathrm{Ca}^{2+} ; 7$ - мелкая часть шельра, прибрежная зона и островная часть шельра до 25 м,

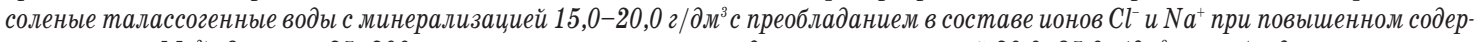
жании ионов $\mathrm{Mg}^{2+} ; 8$ - море, 25-200 м, соленые талассогенные воды с минерализацией 20,0-35,0 г/дл ${ }^{3}$ с преобладанием в составе ионов $\mathrm{Cl}^{-}$и $\mathrm{Na}^{+}$при повышенном содержании ионов $\mathrm{Mg}^{2+} ; 9$ - глубокое море 200-400 м, соленые талассогенные воды с минерали-

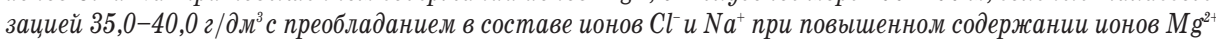

Fig. 3. Paleohydrogeochemical map for the Oxfordian age: 1 - the boundary of the Jurassic sedimentary basin; 2 - border of paleohydrogeochemical zones: 3 - low mountains, infiltration of fresh meteogenic waters with mineralization up to $0,5 \mathrm{~g} / \mathrm{dm}^{3} \mathrm{dominates} \mathrm{with} \mathrm{prevalence} \mathrm{of}$ $\mathrm{HCO}_{3}{ }_{3}^{-}$and $\mathrm{Ca}^{2+}$ ions; 3 - elevated plain, fresh and brackish infiltrogenic waters with mineralization of $0,5-1,5 \mathrm{~g} / \mathrm{dm}^{3}$ with prevalence of $\mathrm{HCO}_{3}{ }^{-}$and $\mathrm{Ca}^{2+}$ ions in composition with increased content of $\mathrm{Cl}^{-}$and $\mathrm{Na}^{+} ; 4$ - plain denudation-accumulative, fresh and brackish infiltrogenic waters with mineralization of 1,5-2,0 $\mathrm{g} / \mathrm{dm}^{3}$ with prevalence in composition of $\mathrm{HCO}_{3}^{-}$and $\mathrm{Ca}^{2+}$ ions with increased content of $\mathrm{Cl}^{-}$and $\mathrm{Na}^{+} ; 5$ - low plain accumulation, burial of brackish water with salinity of 2,0-5,0 $\mathrm{g} / \mathrm{dm}^{3}$ and predominance of elevated levels of $\mathrm{HCO}_{3}{ }^{-}$and $\mathrm{Ca}^{2+}$ in composition of $\mathrm{Cl}^{-}$and $\mathrm{Na}^{+}$ions; 6 - coastal plain, syngenetic brackish waters with salinity of 5,0-15,0 $\mathrm{g} / \mathrm{dm}^{3}$ with predominance of $\mathrm{Cl}^{-}$and $\mathrm{Na}^{+}$ions in composition with increased content of $\mathrm{Mg}^{2+}$ and $\mathrm{Ca}^{2+}$ ions; 7 - small part of the shelf, coastal zone and island part of the shelf up to $25 \mathrm{~m}$, salted thalassogenic waters with salinity of 15,0-20,0 $\mathrm{g} / \mathrm{dm}^{3}$ with prevalence of $\mathrm{Cl}^{-}$and $\mathrm{Na}^{+}$ions in composition with increased $\mathrm{Mg}^{2+}$ ion content; 8- sea, 25-200 m, salted thalassogenic waters with mineralization of 20,0-35,0 g/ $\mathrm{dm}^{3}$ with prevalence of $\mathrm{Cl}^{-}$and $\mathrm{Na}^{+}$ions in composition with increased content of $\mathrm{Mg}^{2+}$ ions; 9 - deep sea 200-400 $\mathrm{m}$, salted thalassogenic waters with mineralization of 35,0-40,0 $\mathrm{g} / \mathrm{dm}^{3}$ with prevalence of $\mathrm{Cl}^{-}$and $\mathrm{Na}^{+}$ions in composition with increased content of $\mathrm{Mg}^{2+}$ ions

зацией 5-15 г/дм³. Зона обстановок глубоководного осадконакопления заметно уменьшилась и существовала в центральной части территории исследования. В готериве Западно-Сибирский бассейн претерпел значительное опреснение ввиду его обмеления из-за потери связи с бореальными морями [67]. В западной части Гыданского полуострова сохранилась глубоководная зона небольшой площади, а зона мелководья, занимавшая восточную часть региона, значительно увеличилась. В южной части региона доминировали обстановки прибрежной равнины, где захоронялись солоноватые хло- ридные натриевые воды с минерализацией 2-5 г/дм³ при повышенных содержаниях гидрокарбонат-иона и катионов кальция в составе. В течение баррема и сеномана при смене обстановок осадконакопления [67] происходили процессы опреснения инфильтрационных метеогенных вод $\left(\mathrm{HCO}_{3} \mathrm{Ca}\right)$ с минерализацией до 2 г/дм ${ }^{3}$. С турона по кампан при трансгрессии в регионе доминировала зона мелководья, а на юго-западе, в более глубоководных частях бассейна, соленость вод достигала 15 г/дм ${ }^{3}$ В начале туронско-серраваллийского гидрогеологического цикла в регионе доминировали 


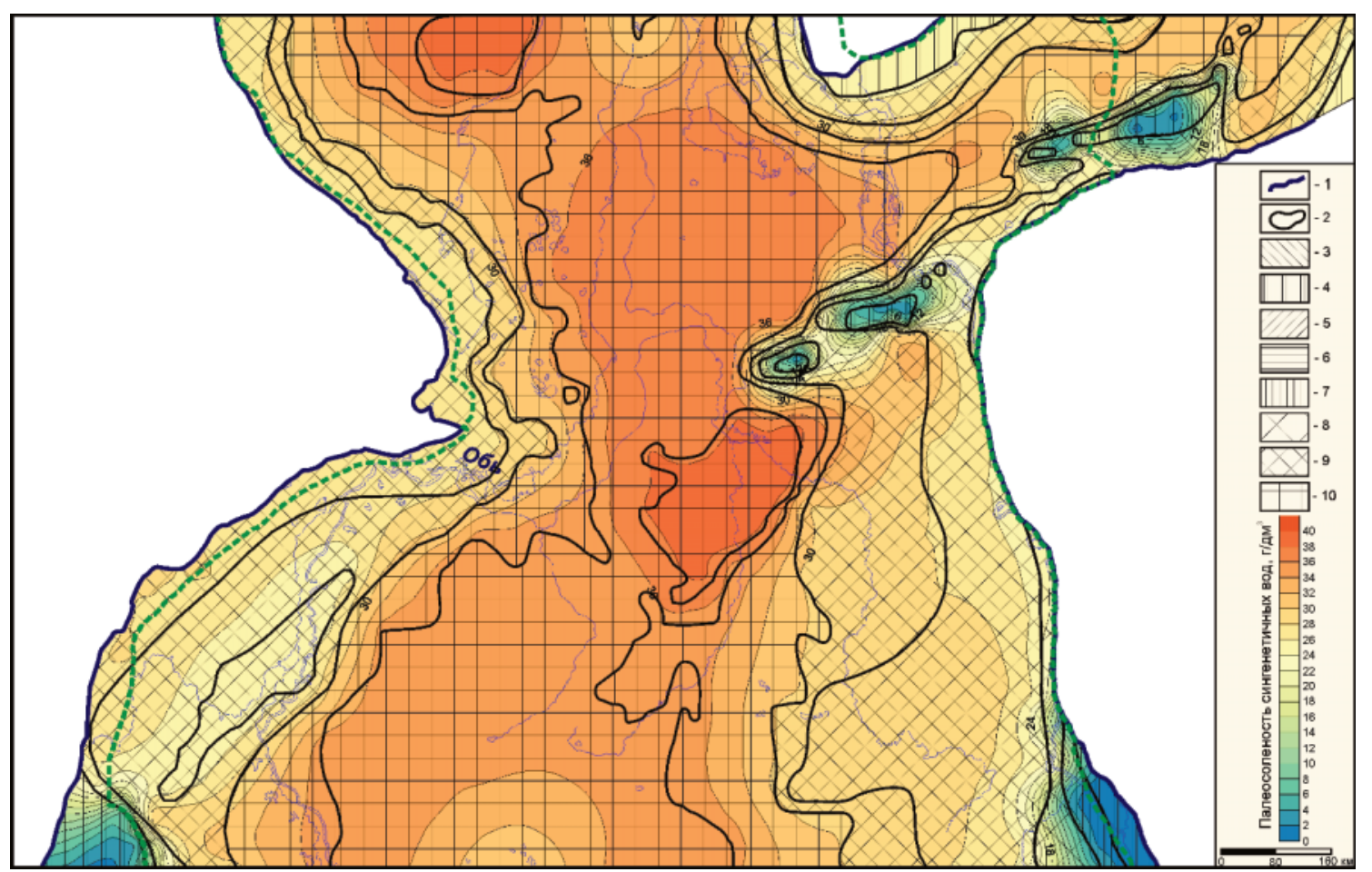

Pис. 4. Палеогидрогеохимическая карта на волжский век. Усл. обозначения сл. на рис. 3

Fig. 4. Paleohydrogeochemical map for the Volgian age. For legend, see Fig. 3

мелководно-морские обстановки с глубинами моря до 100 м. Сингенетичные воды при позднекампанской регрессии были преимущественно инфильтрогенные, гидрокарбонатного кальциевого состава с минерализацией $2-5$ г/дм ${ }^{3}$ и повышенным содержанием ионов натрия и хлора.

Современный химизм подземных вод отложений юры и мела арктических районов Западной Сибири является продуктом длительной эволюции системы «вода-порода-газ-ОВ». Рассмотрим подробнее изменение гидрогеохимии сингенетичных вод оксфордского регионального резервуара с момента захоронения до настоящего времени.

\section{Сравнительный анализ гидрогеохимии верхнеюрских} отложений с момента захоронения до наших дней

На формирование современного облика гидрогеохимического поля оксфордского регионального резервуара северных и арктических районов ЗСОБ оказали влияние процессы: 1) уплотнения осадков под действием геостатической нагрузки, сопровождающиеся отжатием физически-связанных вод; 2) термодегидратации глинистых минералов основных флюидоупоров при вхождении их в диапазон пластовых температур $100{ }^{\circ} \mathrm{C}$ и более и как следствие появление в гидрогеологическом разрезе литогенных (химически-связанных, возрожденных) вод низкой минерализации; 3) межпластовых перетоков из отложений палеозойского фундамента в зонах отсутствия триасовых отложений; 4) преобразования органического вещества основных нефтематеринских свит и нефтегазообразования и 5) взаимодействия в системе «вода-порода».
При сравнительном анализе захороненных сингенетичных вод оксфордского бассейна и данных по современной гидрогеохимии подземных вод установлены весьма значительные различия (рис. 5). Выявлены области положительных и отрицательных аномалий, в первую очередь по величине общей минерализации. Положительные аномалии характеризуются ростом общей минерализации изначально захороненных вод на 10 г/дм ${ }^{3}$ и более, а отрицательные аномалии - ее снижением на 15 г/дм ${ }^{3}$ и выше. В первом случае большинство аномалий приурочены к структурам Южно-Надымской (Известинское, Комсомольское, Вынгапуровское и другие месторождения) и Предъенисейской мегамоноклизы (Черничное и Термокарстовое месторождения). Отрицательные аномалии закономерно трассируют границу глинизации оксфордского регионального резервуара в центральных районах Надым-Тазовского междуречья, значительно расширяясь в северо-восточном направлении и захватывая практически всю территорию прилегающих районов Енисей-Хатангского регионального прогиба, а также охватывают центральные районы Красноселькупской и западные Предъенисейской мегамоноклизы (рис. 5).

Природа положительных аномалий связана с широко проявившимися процессами вертикальной разгрузки подземных вод нижне-среднеюрского и палеозойского водоносных комплексов в зонах тектонических нарушений, о чем мы писали ранее [58-61]. Так, в скважинах 45, 49 и 608 Губкинского месторождения подземные воды батского и оксфордского горизонтов схожи по содержанию брома, 


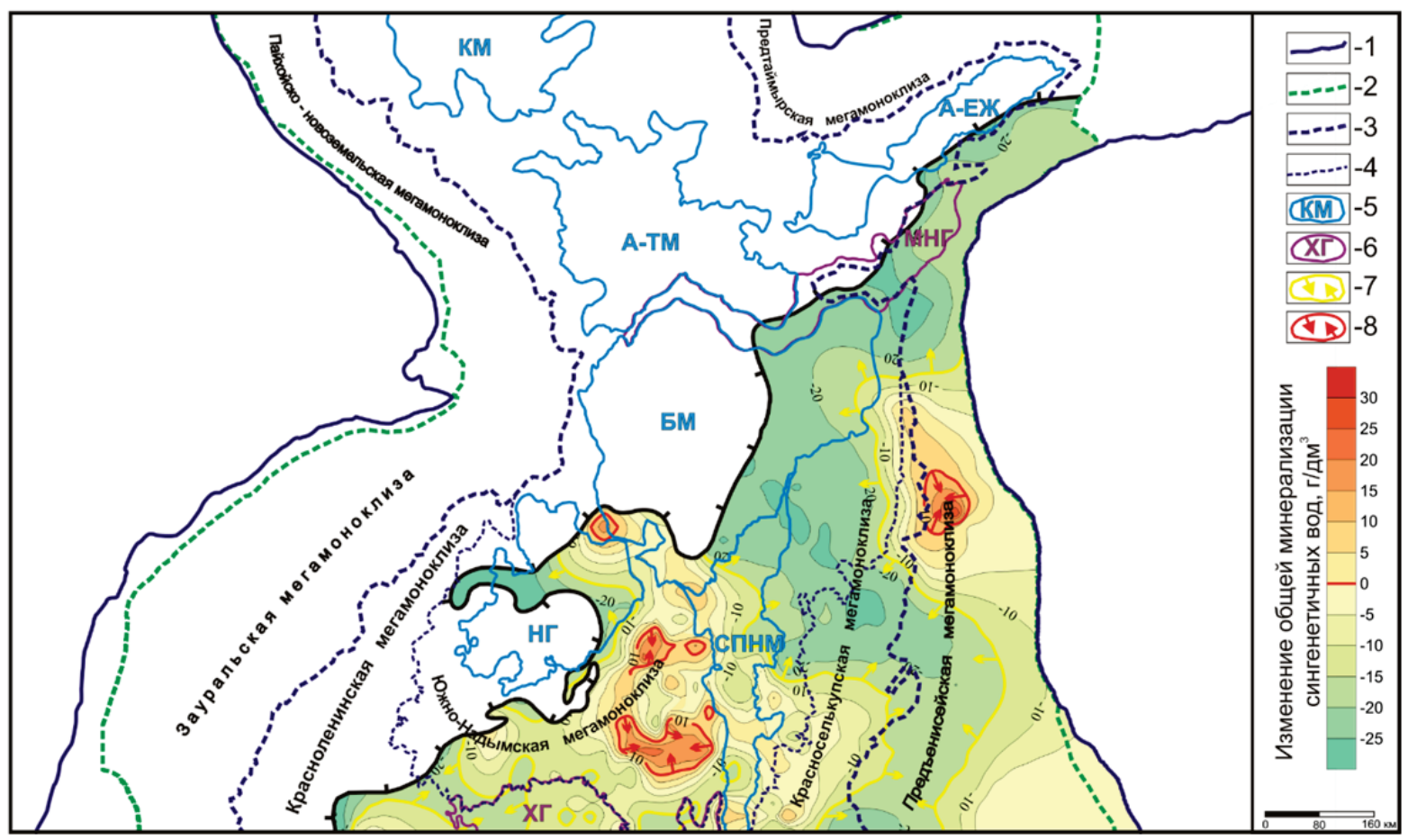

Рис. 5. Изленение величины общей минерализации сингенетичных вод оксфордского регионального резервуара с молента захоронения до наших дней. Гранииы: 1 - Западно-Сибирского осадочного бассейна; 2 - юрского осадочного бассейна; 3 - Внутренней области и Внешнего пояса; 4 - Ямало-Карской депрессии; 5 - положительные тектонические элеленты - структуры 0 порядка: КМ Карская мегасинеклиза, А-ТМ - Антипаютинско-Тадебеяхинская мегасинеклиза, А-ЕЖ - Агапско-Енисейский желоб, БМ Большехетская мегасинеклиза, НГ - Надылскал гелисинеклиза, СПНМ - Среднепурский наклонный мегажелоб; 6 - отрицательные тектонические элементы - структуры 0 порядка: МНГ - Мессояхская наклонная гряда, ХГ - Хантейская гемисинеклиза. Гидрогеохимические аномалии, связанные с процессом: 7 -терлодегидратаиии глинистых минералов; 8 - разгрузки подземных вод нижне-среднеюрского и палеозойского водоносных колплексов

Fig. 5. Changes in the total mineralization of the syngenetic waters of the Oxford regional reservoir from the moment of burial to the present day. Borders: 1 - West Siberian sedimentary basin; 2 - Jurassic sedimentary basin; 3 - Inner region and Outer belt; 4 - Yamalo-Kara depression; Positive tectonic elements - structures of 0 order: KM - Kara megasyneclise, A-TM - Antipayutinsko-Tadebeyakha megasyneclise, A-EЖ - Agapsko-Yenisei trough, БM - Bolshekhetskaya megasineklise, HГ - Nadym hemisineclise, CПHM - Srednepursky

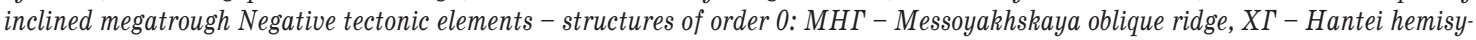
neclise. Hydrogeochemical anomalies associated with the process: 7 - termodehydration of clay minerals; 8 - groundwater discharge from the Lower Middle Jurassic and Paleozoic aquifer complexes

бора, йода и нафтеновых кислот, а также по величине общей минерализации. Изучение распределения нормированных по хлору концентраций основных катионов (натрия, кальция, магния и калия) выявило закономерную смену химических типов подземных вод от наиболее соленых хлоридных натриевых к гидрокарбонатно-хлоридным натриевым. В этом же направлении происходит снижение степени метаморфизации подземных вод и их родства с морскими водами (рис. 6). Обширные области опреснения изучаемого резервуара (отрицательные аномалии) связаны с широким проявлением процессов термодегидратации глинистых минералов.

Как показано в работах $[67,68]$, с глубин около 2 км начинается дегидратация (отжатие межслоевой воды) глинистых минералов, которая проходит в несколько стадий. Д.Б. Шоу для более чем 2000 месторождений США рассчитал глубины и температуры дегидратации глин и установил, что глубины обезвоживания меняются в пределах $1280-4850$ м, а температуры при этом варьируют в пределах $83-111^{\circ} \mathrm{C}$ [69]. Такой широкий интервал глубин в первую очередь связывается с разной величиной теплового потока на изучаемых месторождениях.

Учитывая результаты геотермических исследований осадочного чехла Западной Сибири, полученные Г.Д. Гинсбургом, А.Д. Дучковым, Ю.Г. Зиминым, А.Э. Конторовичем, В.А. Кошляком, Н.М. Кругликовым, А.Р. Курчиковым, Б.Ф. Маврицким, И.И. Нестеровым, Б.П. Ставицким, Э.Э. Фотиади, Г.А Череменским и другими, и вытекающие из них модели геотемпературного поля, можно предполагать, что в пределах изучаемого региона элизионная геостатическая (литостатическая) система с глубины около 2-2,5 км, где начинают проявляться аномально-высокие пластовые давления (АВПД), приобретает черты термодегидратационной [58, 70].

Анализ напряженности гидродинамического поля в пределах оксфордского резервуара выявил наличие давлений: от нормальных на востоке до повышенных, переходящих в аномально высокие, 

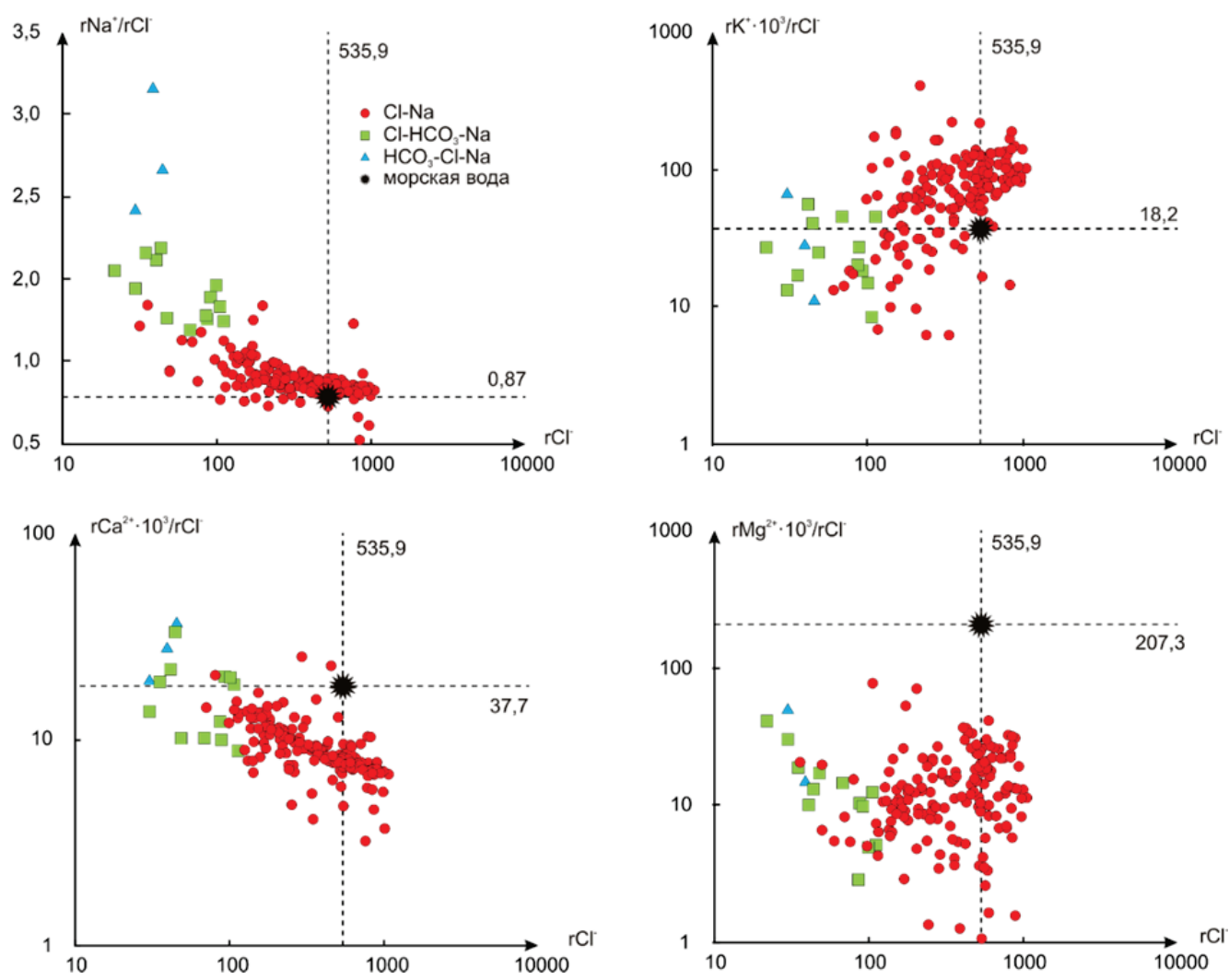

Pис. 6. Распределение содержаний натрия, калия, кальция и магния, норлированных по хлору кего концентрации в подзелных водах оксфордского регионального резервуара северных и арктических районов ЗСОБ

Fig. 6. Distribution of sodium, potassium, calcium and magnesium contents, normalized by chlorine to its concentration in the groundwater of the Oxford regional reservoir of the northern and arctic regions of the WSSB

в западных и центральных районах Ямало-Карской депрессии. На фоне нормальных пластовых давлений в восточной области изучаемого региона в пределах Ютырмальского, Текто-Харампурского и Равнинного месторождений установлены гидродинамические аномалии с повышенными давлениями, что говорит о вертикальных перетоках из более глубоких горизонтов. Наличие зоны АВПД поблизости с границей распространения оксфордского регионального резервуара в западной и центральной частях Надым-Тазовского междуречья связано с элизионным типом режима в этой области [34]. Согласно нашим исследованиям, здесь элизионная геостатическая (литостатическая) водонапорная система приобретает черты термодегидратационной, поскольку пластовые температуры превышают 100 C [58-66, 71, 72].

Как показали результаты палеогидрогеохимических реконструкций, состав подземных вод верхнеюрских отложений северных и арктических районов ЗСОБ был сформирован в осадочном бассейне, заполненном преимущественно седиментационными водами. На основе сравнения состава седиментогенных и морских вод установлено, что именно морские воды послужили источником для седиментогенных [8, 56]. Среди микрокомпонентов наибольшая степень концентрирования отме- чается среди биогенных, таких как: I (89-387), $\mathrm{NH}_{4}(99-110), \mathrm{SiO}_{2}(6-17), \mathrm{B}(3-10)$ и $\mathrm{Br}(1-1,3)$ $[58,62]$. Основными факторами формирования химического состава подземных вод следует считать процессы взаимодействия в системе «вода-порода-газ-ОВ» [58, 73, 74].

\section{Заключение}

Из вышесказанного можно сделать следующие выводы: 1) Преимущественно морской режим осадконакопления в мезозое господствовал в северных и арктических районах Западной Сибири до конца готеривского века и практически на протяжении всего верхнего мела, наиболее глубоководным бассейн был в волжское время. 2) Существенного изменения химического состава Арктического бассейна на границах триасового и юрского периодов не произошло. Фиксировались закономерные уменьшения концентраций калия и натрия и увеличение суммы кальция и магния. На рубеже средней и поздней юры из-за углубления бассейна минерализация сингенетичных вод могла достигать 35-38 г/дм ${ }^{3}$. 3) На основе анализа современной гидрогеохимии нефтегазоносных отложений с учетом палеогидрогеохимических реконструкций установлено, что в разрезе доминируют седиментогенные воды, в некоторых случаях разбавленные 
инфильтрогенными, проникшими при регрессии морского бассейна, что хорошо согласуется с результатами последних палеогеографических построений на юрский и меловой периоды, выполненных в ИНГГ СО РАН под руководством академика А.Э. Конторовича $[56,57]$. 4) Сравнительный анализ захороненных сингенетичных вод оксфордского бассейна и данных по современной гидрогеохимии подземных вод верхнеюрского водоносного комплекса выявил весьма значительные различия. По величине общей минерализации выявлены области положительных и отрицательных аномалий. В первом случае большинство аномалий приурочены к структурам Южно-Надымской и Предъенисейской мегамоноклиз, где широко проявлены процессы вертикальной разгрузки подземных вод нижне-среднеюрского и палеозойского водоносных комплексов в зонах тектонических нарушений. Отрицательные аномалии закономерно трассируют границу глинизации оксфордского регионального резервуара в центральных районах Надым-Тазовского междуречья, значительно расширяясь в северо-восточном направлении и захватывая практически всю территорию прилегающих районов Енисей-Хатангского регионального про-

1. Чирвинский П.Н. Палеогидрогеология // Проблемы современной геологии. - 1933. - Т. 3. - № 8. - С. 107-122.

2. Карцев А.А. Гидрогеология нефтяных и газовых месторождений. - М.: Гостоптехиздат, 1963. - 353 с.

3. Карцев А.А., Вагин С.Б., Басков Е.А. Палеогидрогеология. М.: Недра, 1969. - 152 c.

4. Грамберг И.С. Палеогидрогеохимия терригенных толщ. - Л.: Недра, 1973. - 172 с.

5. Никаноров А.М., Волобуев Г.П., Барцев О.Б. Палеогидрогеологические реконструкции нефтегазоносных бассейнов. - М.: Недра, 1975. - 192 c.

6. Басков Е.А. Основы палеогидрогеологии рудных месторождений. - Л.: Недра, 1983. - 263 с.

7. Ходжакулиев Я.А., Абукова Л.А. Палеогидрогеологические исследования при поисках нефти и газа. - М.: Недра, 1985. 209 c.

8. Sadykova Y.V., Dultseva M.G. The role of paleohydrochemical factors in groundwater chemistry formation in oil-and-gas-bearing deposits of the northeastern Bol'shekhetskaya Megasyneclise // Water Resources. - 2017. - V. 44. - № 2. - P. 246-258.

9. Anadon P., Julia R. Hydrochemistry from $\mathrm{Sr}$ and $\mathrm{Mg}$ contents of ostracodes in Pleistocene lacustrine deposits, Baza Basin (SE Spain) // Hydrobiologia. - 1990. - № 197. - P. 291-303.

10. Bish D.L., Aronson J.L. Paleogeothermal and paleohydrologic conditions in silicic tuff from Yucca Mountain, Nevada // Clays Clay Miner. - 1993. - № 41. - P. 148-161.

11. Cheikh N.B., Zouari K., Abidi B. Geochemical and isotopic study of paleogroundwater salinization in southern Tunisia (Sfax basin) // Quat Int. - 2012. - V. 257. - P. 34-42.

12. Drake H., Tullborg E.L. Paleohydrogeological events recorded by stable isotopes, fluid inclusions and trace elements in fracture minerals in crystalline rock, Simpevarp area, SE Sweden // Appl Geochem. - 2009. - № 24. - P. 715-732.

13. Dublyansky Yu.V., Spötl C. Evidence for a hypogene paleohydrogeological event at the prospective nuclear waste disposal site Yucca Mountain, Nevada, USA, revealed by the isotope composition of fluid-inclusion water // Earth and Planetary Science Let- гиба, а также охватывают центральные районы Красноселькупской и западные Предъенисейской мегамоноклизы. Их природа связана с развитием процессов элизионного водообмена. Геостатическая (литостатическая) водонапорная система на глубинах 2-2,5 км переходит в термодегидратационную, что проявляется появлением АВПД. 5) За счет метаморфизма рассеянного органического вещества воды обогатились биогенными элементами (йод, бор, аммоний, фосфор и т. д.). По сравнению с морской водой у них отмечается наибольшая степень концентрирования: аммоний $(99-110)$ и йод (89-387), средняя - бор (3-10) и кремнезем $(6-17)$ и низкая - бром $(1-1,3)[58,70$, 74]. 6) Системе «вода-порода-газ-органическое вещество» принадлежит ключевая роль в процессах формирования химического состава подземных вод нефтегазоносных отложений.

Исследования проводились при финансовой поддержке проекта ФНИ № 0331-2019-0025 «Геохимия, генезис и механизмы форлирования состава подземных вод арктических районов осадочных бассейнов Сибири» и Российского фонда фундалентальных исследований в рамках научного проекта № 18-05-70074 «Ресурсы Арктики».

\section{СПИСОК ЛИТЕРАТУРЫ}

ters. - 2010. - № 289. - P. 583-594.

14. Oxygen isotope studies of illite/smectite and clinoptilolite from Yucca Mountain: implications for paleohydrologic conditions / X. Feng, A.M. Faiia, G.G. Wolde, J.L. Aronson, M.A. Poage, C.P. Chamberlain // Earth Planet. Sci. Lett. - 1999. - № 171. P. 95-106.

15. Forester R.M., Lowenstein T.K., Spencer R.J. An ostracode based paleolimnologic and paleohydrologic history of Death Valley: 200 to $0 \mathrm{ka} / /$ Geol. Soc. Am. Bull. - 2005. - № 117. P. $1379-1386$.

16. Paleohydrological and paleoenvironmental changes recorded in terrestrial sediments of the Paleocene-Eocene boundary (Normandy, France) / S. Garel, J. Schnyder, J. Jacob, C. Dupuis, M. Boussafir, C. Le Milbeau, J.-Y. Storme, A.I. Iakovleva, J. Yans, F. Baudin, C. Fléhoc, F. Quesnel // Palaeogeography, Palaeoclimatology, Palaeoecology. - 2013. - V. 376. - P. 184-199.

17. Palaeohydrological evolution of the late Cenozoic saline lake in the Qaidam Basin, NE Tibetan Plateau: Tectonic vs. climatic control / P. Guo, C. Liu, L. Huang, M. Yu, P. Wang, G. Zhang // Global and Planetary Change. - 2018. - V. 165. - P. 44-61.

18. Palaeohydrogeological insights from natural tracer profiles in aquitard porewater, Great Artesian Basin, Australia / G.A. Harrington, W.P. Gardner, B.D. Smerdon, M.J. Hendry // Water Resources Research. - 2013. - V. 49. - Iss. 7. - P. 4054-4070.

19. Paleohydrogeology of the Cretaceous sediments of the Williston Basin using stable isotopes of water / M.J. Hendry, S.L. Barbour, K. Novakowski, L.I. Wassenaar // Water Resources Research. 2013. - V. 49. - P. 4580-4592.

20. Linkages between Holocene paleoclimate and paleohydrogeology preserved in a Yucatan underwater cave / P.J. Hengstum, E.G. Reinhardt, P.A. Beddows, J.J. Gabriel / / Quaternary Science Reviews. - 2010. - № 29. - P. 2788-2798.

21. Hill C.L., Schild R. Paleohydrology and paleoenvironments at Bir Sahara: Pleistocene lithostratigraphy and sedimentology in the southern Egyptian Sahara // Journal of African Earth Sciences. -2017 . - V. 136. - P. 201-215.

22. Epigenetic dolomitization and iron mineralization along faults and 
their possible relation to the paleohydrology of southern Israel S. Ilani, E. Rosenthal, J. Kronfeld, A. Flexer // Appl Geochem. 1988. - № 3. - P. 487-498.

23. Bromine and stable isotopic profiles of formation waters from potash mine-shafts, Saskatchewan, Canada / G.K.S. Jensen, B.J. Rostron, M.J.M. Duke, C. Holmden // Journal of Geochemical Exploration. - 2006. - № 89. - P. 170-173.

24. Paleohydrogeological and thermal events recorded by fluid inclusions and stable isotopes of diagenetic minerals in Lower Cretaceous sandstones, offshore Nova Scotia, Canada / A. Karim, J.J. Hanley, G. Pe-Piper, D.J.W. Piper // AAPG Bulletin. 2012. - Iss. 6. - P. 1147-1169.

25. Khan Z.A., Tewari R.C. Paleochannel and paleohydrology of a Middle Siwalik (Pliocene) fluvial system, northern India // Journal of Earth System Science. - 2011. - V. 120. - Iss. 3. P. 531-543.

26. Fracture-controlled paleohydrogeology in a basement-cored, fault-related fold: Sheep Mountain Anticline, Wyoming, United States / N. Beaudoin, N. Bellahsen, 0. Lacombe, L. Emmanuel // Geochem. Geophys. Geosyst. - 2011. - V. 12. - № 6. № Q06011.

27. Kraemer T.F., Wood W.W., Sanford W.E. Distinguishing seawater from geologic brine in saline coastal groundwater using radium-226; an example from the Sabkha of the UAE // Chemical Geology. - 2014. - № 371. - P. 1-8.

28. Paleohydrologic response to continental warming during the $\mathrm{Pa}$ leocene-Eocene Thermal Maximum, Bighorn Basin, Wyoming / M.J. Kraus, F.A. McInerney, S.L. Wing, R. Secord, A.A. Baczynski, J.I. Bloch // Palaeogeography, Palaeoclimatology, Palaeoecology. - 2013. - V. 370. - P. 196-208.

29. Li Y., Wang Y., Deng A. Paleoclimate record and paleohydrogeological analysis of travertine from the Niangziguan Karst Springs, northern China // Science in China. - 2001. - V. 44. P. $114-118$.

30. High-resolution palaeohydrological reconstruction of central Italy during the Holocene / M. Marchegiano, A. Francke, E. Gliozzi, B. Wagner, D. Ariztegui // Holocene. - 2019. - V. 29 (3). P. 481-492.

31. Paleoenvironmental and paleohydrochemical conditions of dolomite formation within a saline wetland in arid northwest Australia / C.C. Mather, G. Skrzypek, S. Dogramaci, P.F. Grierson // Quaternary Science Reviews. - 2018. - V. 185. - P. 172-188.

32. Milodowski A.E., Bath A., Norris S. Palaeohydrogeology using geochemical, isotopic and mineralogical analyses: Salinity and redox evolution in a deep groundwater system through Quaternary glacial cycles // Applied Geochemistry. - 2018. - V. 97. P. 40-60.

33. Geochronology of late Pleistocene to Holocene speleothems from central Texas: implications for regional paleoclimate / M. Musgrove, J.L. Banner, L.E. Mack, D.M. Combs, E.W. James, H. Cheng, R.L. Edwards // Geol. Soc. Am. Bull. - 2001. № 113. - P. 1532-1543.

34. Chemical evolution of saline waters in the Jordan-Dead Sea transform and in adjoining areas / P. M?ller, E. Rosenthal, S. Geyer, A. Flexer // Int J Earth Sci (Geol Rundsch). - 2007. - № 96. P. 541-566.

35. U-Pb ages of secondary silica at Yucca Mountain, Nevada: implications for the paleohydrology of the unsaturated zone / L.A. Neymark, Y.V. Amelin, J.B. Paces, Z.E. Peterman // Appl. Geochem. - 2002. - № 17. - P. 709-734.

36. Major hydrological regime change along the semiarid western coast of South America during the early Holocene / C. Ortega, G. Vargas, J.A. Rutllant, D. Jackson, C. M?ndez // Quaternary Research (United States). - 2012. - V. 78. - Iss. 3. - P. 513-527.

37. Limited hydrologic response to Pleistocene climate change in deep vadose zones - Yucca Mountain, Nevada / J.B. Paces, L.A. Neymark, J.F. Whelan, J.L. Wooden, S.P. Lund, B.D. Marshall //
Earth and Planetary Science Letters. - 2010. - № 300. P. 287-298.

38. Paces J.B., Whelan J.F. The paleohydrology of unsaturated and saturated zones at Yucca Mountain, Nevada, and vicinity // Memoir of the Geological Society of America. - 2012. - V. 209. P. 219-276.

39. Improving paleohydrological and diagenetic reconstructions in calcite veins and breccia of a sedimentary basin by combining $\Delta 47$ temperature, $\delta 180$ water and U-Pb age / M. Pagel, M. Bonifacie, D.A. Schneider, C. Gautheron, B. Brigaud, D. Calmels, A. Cros, B. Saint-Bezar, P. Landrein, C. Sutcliffe, D. Davis, C. Chaduteau // Chemical Geology. - 2018. - V. 481. - P. 1-17.

40. Quade J., Forester R.M., Whelan J.F. Late Quaternary paleohydrologic and paleotemperature change in southern Nevada // Paleoenvironments and Paleohydrology of the Mojave and Southern Great Basin Deserts: Geol. Soc. of Amer. Spec. Paper. - 2003. № 368. - P. 165-188.

41. Rosenthal E., Flexer A., Möller P. The paleoenvironment and the evolution of brines in the Jordan-Dead Sea transform and in adjoining areas // Int J Earth Sci. - 2006. - № 95. - P. 725-740.

42. Rosenthal E., Jones B.F., Weinberger G. The chemical evolution of Kurnub Group paleowater in the Sinai-Negev province - a mass balance approach // Appl. Geochem. - 1998. - № 27. P. 3-17.

43. Stable isotope paleohydrology and chemostratigraphy of the Albian Wayan Formation from the wedge-top depozone, North American Western Interior Basin / J.B. Ross, G.A. Ludvigson, A. Möller, L.A. Gonzalez, J.D. Walker // Science China Earth Sciences. - 2017. - V. 60. - Iss. 1. - P. 44-57.

44. Sadofsky S. J., Bebout G. E. Field and isotopic evidence for fluid mobility in the franciscan complex: forearc paleohydrogeology to depths of 30 kilometers // International Geology Review. 2004. - V. 46. - № 12. - P. 1053-1088.

45. A hydrogeologic model of stratiform copper mineralization in the Midcontinent Rift Sestem, Northern Michigan, USA / J.B. Swenson, M. Person, J.P. Raffensperger, W.F. Cannon, L.G. Woodruff, M.E. Berndt // Geofluids. - 2004. - № 4. - P. 1-22.

46. Veizer J., Prokoph A. Temperatures and oxygen isotopic composition of Phanerozoic oceans // Earth-Science Reviews. - 2015. № 146. - P. 92-104.

47. Wallin B, Peterman Z. Calcite fracture fillings as indicators of paleohydrology at Laxemar at the Äspö Hard Rock Laboratory, southern Sweden // Appl Geochem. - 1999. - № 14. P. 953-962.

48. Constraining the inferred paleohydrologic evolution of a deep unsaturated zone in the Amargosa Desert / M.A. Walvoord, D.A. Stonestrom, B.J. Andraski, R.G. Striegl / / Vadose Zone J. 2004. - № 3. - P. 502-512.

49. Yousif M., Henselowsky F., Bubenzer 0. Palaeohydrology and its impact on groundwater in arid environments: Gebel Duwi and its vicinities, Eastern Desert, Egypt // Catena. - 2018. - V. 171. P. 29-43.

50. Comprasion of carbonate $\mathrm{C}$ and $\mathrm{O}$ stable isotope records across the Jurassic/Cretaceous boundary in the Tethyan and Boreal Realms / K. Zak, M. Kostak, O. Man, V.A. Zakharov, M.A. Rogov, P. Pruner, J. Rohovec, O.S. Dzyuba, M. Mazuch // Palaeogeography, Paleoclimatology, Palaeoecology. - 2011. - № 299. - P. 83-96.

51. Палеогидрогеохимия верхнеюрских отложений арктических районов Западной Сибири / Я.В. Садыкова, Д.А. Новиков, А.В. Черных, Ф.Ф. Дульцев // Подземные воды Востока России: Материалы Всероссийского совещания по подземным водам Востока России (XXII Совещание по подземным водам Сибири и Дальнего Востока с международным участием). - Новосибирск, ИНГГ СО РАН, 2018. - С. 412-417.

52. Novikov D.A., Chernykh A.V., Dultsev F.F. Paleohydrogeochemistry of the Upper Jurassic Deposits of the Arctic Regions of the West Siberian Megabasin // Journal of Physics: Conference Seri- 
es. - 2019. - V. 1172 (1). - № 012094.

53. Геология нефти и газа Западной Сибири / А.Э. Конторович, И.И. Нестеров, Ф.К. Салманов, В.С. Сурков, А.А. Трофимук, Ю.Г. Эрвье. - М.: Недра, 1975. - 680 с.

54. Конторович А.Э. Пути освоения ресурсов нефти и газа российского сектора Арктики // Вестник Российской Академии Наук. - 2015. - T. 85. - № 5-6. - C. 420-430.

55. Карцев А.А., Абукова Л.А., Абрамова 0.П. Словарь по нефтегазовой гидрогеологии. - М.: ГЕОС, 2015. - 304 c.

56. Палеогеография Западно-Сибирского осадочного бассейна в юрском периоде / А.Э. Конторович, В.А. Конторович, С.В. Рыжкова, Б.Н. Шурыгин, Л.Г. Вакуленко, Е.А. Гайдебурова, В.П. Данилова, В.А. Казаненков, Н.С. Ким, Е.А. Костырева, В.И. Москвин, П.А. Ян // Геология и геофизика. 2013. - T. 54. - № 8. - Р. 972-1012.

57. Палеогеография Западно-Сибирского осадочного бассейна в меловом периоде / А.Э. Конторович, С.В. Ершов, В.А. Казаненков, Ю.Н. Карогодин, В.А. Конторович, Н.К. Лебедева, Б.Л. Никитенко, Н.И. Попова, Б.Н. Шурыгин // Геология и геофизика. - 2014. - V. 55. - № 5-6. - Р. 745-776.

58. Шварцев С.Л., Новиков Д.А. Природа вертикальной гидрогеохимической зональности нефтегазоносных отложений (на примере Надым-Тазовского междуречья, Западная Сибирь) // Геология и геофизика. - 2004. - Т. 45. - № 8. - С. 1008-1020.

59. Новиков Д.А., Лепокуров А.В. Гидрогеологические условия нефтегазоносных отложений на структурах южной части Ямало-Карской депрессии // Геология нефти и газа. - 2005. № 5. - С. 24-33.

60. Новиков Д.А. Гидрогеологические предпосылки нефтегазоносности западной части Енисей-Хатангского регионального прогиба // Геодинамика и тектонофизика. - 2017. - Т. 8. - № 4. C. 881-901.

61. Кох А.А., Новиков Д.А. Гидродинамические условия и вертикальная гидрогеохимическая зональность подземных вод в западной части Хатангского артезианского бассейна // Водные ресурсы. - 2014. - Т. 41. - № 4. - С. 375-385.

62. Novikov D.A., Sukhorukova A.F. Hydrogeology of petroleum deposits in the northwestern margin of the West Siberian Artesian Basin // Arabian Journal of Geosciences. - 2015. - V. 8. № 10. - P. 8703-8719.

63. Новиков Д.А., Вакуленко Л.Г., Ян П.А. Особенности латеральной гидрогеохимической и аутигенно-минералогической 30 нальности оксфордского регионального резервуара Надым-Та- зовского междуречья // Геология и геофизика. - 2019. T. 60. - № 6. - C. 843-859.

64. Novikov D.A. Chemical equilibrium of groundwater with minerals of the host rocks in Upper Jurassic sediments (Arctic regions of Western Siberia) // E3S Web of Conferences. - 2019. V. 98. - № 01037.

65. Novikov D.A. Genetic classification of subsurface waters and brines of Arctic regions of Siberia // IOP Conference Series: Earth and Environmental Science. - 2018. - V. 193 (1). - № 012049.

66. Стратиграфия нефтегазоносных бассейнов Сибири. Юрская система / Б.Н. Шурыгин, Б.Л. Никитенко, В.П. Девятов, В.И. Ильина, С.В. Меледина, Е.А. Гайдебурова, О.С. Дзюба, А.М. Казаков, Н.К. Могучева. - Новосибирск: Изд-во СО РАН, филиал «ГЕО», 2000. - 480 c.

67. Burst J.F. Diagenesis of Gulf Coast Clayey Sediments and Its Possible Relation to Petroleum Migration // AAPG Bulletin. 1969. - V. 53. - № 1. - P. 73-93.

68. Perry E.A., Jr., Hower J. Late-stage dehydration in deeply buried politic sediments // AAPG Bulletin. - 1972. - V. 56. - № 10. P. 2013-2021.

69. Shaw D.B., Weaver C.E. The mineralogical composition of shales // Journal of Sediment Research. - 1965. - V. 35. - № 1. P. 213-222.

70. Новиков Д.А. Разведка месторождений нефти и газа в юрскомеловых отложениях п-ова Ямал на основе изучения водно-газовых равновесий // Нефтяное хозяйство. - 2018. - № 4. C. $16-21$.

71. Новиков Д.А. Роль элизионного водообмена в формировании гидродинамического поля Ямало-Карской депрессии // Литология и полезные ископаемые. - 2019. - № 3. - С. 248-261.

72. Novikov D.A., Dultsev F.F., Chernykh A.V. Abnormally high formation pressures in jurassic-cretaceous reservoirs of Arctic regions of Western Siberia // IOP Conference Series: Earth and Environmental Science. - 2018. - V. 193 (1). - № 012050.

73. Шварцев С.Л. Взаимодействие в системе вода-порода как новая база для развития гидрогеологии // Тихоокеанская геология. - 2008. - Т. 27. - № 6. - С. 5-16.

74. Novikov D.A. Hydrogeochemistry of the Arctic areas of Siberian petroleum basins // Petroleum Exploration and Development. 2017. - V. 44. - № 5. - P. 780-788.

Поступила 25.01.2019 2.

\section{Информация об авторах}

Новиков Д.А., кандидат геолого-минералогических наук, заведующий лабораторией гидрогеологии осадочных бассейнов Сибири Института нефтегазовой геологии и геофизики им. А.А. Трофимука СО РАН; доцент кафедры геологии месторождений нефти и газа и кафедры общей и региональной геологии Новосибирского национального исследовательского государственного университета.

Черных A.B., младший научный сотрудник лаборатории гидрогеологии осадочных бассейнов Сибири Института нефтегазовой геологии и геофизики им. А.А. Трофимука СО РАН.

Садыкова Я.B., кандидат геолого-минералогических наук, старший научный сотрудник лаборатории гидрогеологии осадочных бассейнов Сибири Института нефтегазовой геологии и геофизики им. А.А. Трофимука СО PAH.

Дульщев Ф.Ф., младший научный сотрудник лаборатории гидрогеологии осадочных бассейнов Сибири Института нефтегазовой геологии и геофизики им. А.А. Трофимука CO PAН.

Хилько В.A., младший научный сотрудник лаборатории гидрогеологии осадочных бассейнов Сибири Института нефтегазовой геологии и геофизики им. А.А. Трофимука СО РАН.

Юрчик И.И., кандидат геолого-минералогических наук, младший научный сотрудник лаборатории гидрогеологии осадочных бассейнов Сибири Института нефтегазовой геологии и геофизики им. А.А. Трофимука СО $\mathrm{PAH}$. 


\title{
EVOLUTION OF HYDROGEOCHEMICAL FIELD OF NORTH AND ARCTIC REGIONS OF THE WEST SIBERIAN SEDIMENTARY BASIN IN THE MESOZOIC
}

\author{
Dmitry A. Novikov ${ }^{12}$,
}

NovikovDA@ipgg.sbras.ru

Anatoliy V. Chernykh',

ChernykhAV@ipgg.sbras.ru

Yana V. Sadykova',

SadykovaYV@ipgg.sbras.ru

Fedor F. Dultsev',

DultsevFF@ipgg.sbras.ru

\author{
Vasilina A. Khilko', \\ KhilkoVA@ipgg.sbras.ru \\ Irina I. Yurchik', \\ Yurchikl|@ipgg.sbras.ru \\ 1 Trofimuk Institute of Petroleum Geology and Geophysics of SB of RAS, \\ 3/6, Koptyug Avenue, Novosibirsk, 630090, Russia. \\ ${ }^{2}$ Novosibirsk State University, \\ 1, Pirogov street, Novosibirsk, 630090, Russia.
}

The relevance of the work is in identification of fundamental role of paleohydrogeological factors in the evolution of the hydrogeochemical field in the Mesozoic of the West Siberian sedimentary basin northern and arctic regions. For the first time, the paper proposes the mechanism explaining their contribution to formation of hydrogeochemical anomalies in the Oxford reservoir (Upper Jurassic aquiferous complex) of the studied region, where hydrogeochemical inversion is widely developed.

The aim of the research is to identify the features of composition of syngenetic waters disposed together with the sediment in the expelled and infiltration stages of a sedimentary basin on the basis of established cycling hydrogeological history of the West Siberian sedimentary basin northern and arctic regions; to carry out the comparative analysis of the current and syngenetic waters and determine the nature of hydrogeochemical anomalies.

Methods. The methods developed by A.A. Kartseva, S.B. Vagina, E.A. Baskov and other researchers on paleohydrogeological reconstructions of sedimentary basins were used. The periodization of hydrogeological history was carried out, with identification of the main hydrogeological cycles (with the infiltration and elizion stages). Paleohydrogeochemical studies on the Arctic regions of the West Siberian sedimentary basin were carried out for the Jurassic-Cretaceous section using the methodology for reconstructing the salt composition of the waters of ancient marine and alluvial basins, paleogeographic maps and hydrogeochemical database of Siberian sedimentary basins.

Results. The paper introduces the results of paleohydrogeological reconstructions of the West Siberian sedimentary basin northern and arctic regions. It was established that sedimentary waters dominate in the hydrogeological section of the studied region, in some cases diluted with infiltrogenic waters that have penetrated during the regression of the sea basin. A comparative analysis of buried syngenetic waters of the Oxford basin and data on modern hydrogeochemistry of groundwater revealed a number of negative and positive anomalies. Negative anomalies naturally trace the clay boundary of the Oxford regional reservoir and are associated with the development of water exchange elision. The geostatic (lithostatic) water-pressure system at a depth of 2-2,5 km goes into thermo-dehydration, which is accompanied by abnormally high reservoir pressure and the appearance of fresh chemically-bound water in the water-pressure system. Most of the positive anomalies are confined to the structures of the South Nadym and Predisenyskoy mega-monoclise, where the processes of vertical unloading of groundwater of the Lower Middle Jurassic and Paleozoic aquiferous complexes in the zones of tectonic disturbances are widely manifested. The water-rock-gas-organic matter system plays a key role in formation of groundwater chemical composition in oil and gas deposits.

\section{Key words:}

Hydrogeological cycle, paleohydrogeochemistry, infiltration, elision, hydrogeochemistry, Oxford regional reservoir, Western Siberia, Arctic region.

The research was financially supported by the FSR № 0331-2019-0025 «Geochemistry, origin and mechanisms of formation of groundwater composition in Arctic regions of Siberian sedimentary basin» and the Russian Foundation for Basic Research (project № 18-05-70074 Resources of Arctic).

\section{REFERENCES}

1. Chirvinskiy P.N. Paleogidrogeologiya [Paleohydrogeology]. Problemy sovremennoy geologii, 1933, vol. 3, no. 8, pp. 107-122.
2. Kartsev A.A. Gidrogeologiya neftyanykh i gazovykh mestorozhdeniy [Hydrogeology of oil and gas fields]. Moscow, Gostoptekhizdat Publ., 1963. 353 p. 
3. Kartsev A.A., Vagin S.B., Baskov E.A. Paleogidrogeologiya [Paleohydrogeology]. Moscow, Nedra Publ., 1969. 152 p.

4. Gramberg I.S. Paleogidrogeokhimiya terrigennykh tolshch [Paleohydrogeochemistry of terrigenous strata]. Leningrad, Nedra Publ., 1973. $172 \mathrm{p}$.

5. Nikanorov A.M., Volobuev G.P., Bartsev 0.B. Paleogidrogeolo gicheskiye rekonstruktsii neftegazonosnykh basseynov [Paleohydrogeological reconstructions of oil and gas basins]. Moscow, Nedra Publ., 1975. 192 p.

6. Baskov E.A. Osnovy paleogidrogeologii rudnykh mestorozhdeniy [Basics of paleohydrogeology of ore deposits]. Leningrad, Nedra Publ., 1983. $263 \mathrm{p}$.

7. Khodzhakuliev Ya.A., Abukova L.A. Paleogidrogeologicheskie issledovaniya pri poiskakh nefti i gaza [Paleohydrogeological studies in the search for oil and gas]. Moscow, Nedra publ., 1985. 209 p.

8. Sadykova Y.V., Dultseva M.G. The role of paleohydrochemical factors in groundwater chemistry formation in oil-and-gas-bearing deposits of the northeastern Bolshekhetskaya Megasyneclise. Water Resources, 2017, vol. 44, no. 2, pp. 246-258.

9. Anadon P., Julia R. Hydrochemistry from Sr and Mg contents of ostracodes in Pleistocene lacustrine deposits, Baza Basin (SE Spain). Hydrobiologia, 1990, no.197, pp. 291-303.

10. Bish D.L., Aronson J.L. Paleogeothermal and paleohydrologic conditions in silicic tuff from Yucca Mountain, Nevada. Clays Clay Miner, 1993, no. 41, pp. 148-161.

11. Cheikh N.B., Zouari K., Abidi B. Geochemical and isotopic study of paleogroundwater salinization in southern Tunisia (Sfax basin). Quat Int, 2012, vol. 257, pp. 34-42.

12. Drake H., Tullborg E.L. Paleohydrogeological events recorded by stable isotopes, fluid inclusions and trace elements in fracture minerals in crystalline rock, Simpevarp area, SE Sweden. Appl Geochem, 2009, no. 24, pp. 715-732.

13. Dublyansky Yu.V., Spötl C. Evidence for a hypogene paleohydrogeological event at the prospective nuclear waste disposal site Yucca Mountain, Nevada, USA, revealed by the isotope composition of fluid-inclusion water. Earth and Planetary Science Let ters, 2010, no. 289, pp. 583-594.

14. Feng X., Faiia A.M., Wolde G.G., Aronson J.L., Poage M.A., Chamberlain C.P. Oxygen isotope studies of illite/smectite and clinoptilolite from Yucca Mountain: implications for paleohydrologic conditions. Earth Planet. Sci. Lett, 1999, no. 171, pp. $95-106$.

15. Forester R.M., Lowenstein T.K., Spencer R.J. An ostracode based paleolimnologic and paleohydrologic history of Death Valley: 200 to 0 ka. Geol. Soc. Am. Bull, 2005, no. 117, pp. 1379-1386.

16. Garel S., Schnyder J., Jacob J., Dupuis C., Boussafir M., Le Milbeau C., Storme J.-Y., Iakovleva A.I., Yans J., Baudin F., Fléhoc C., Quesnel F. Paleohydrological and paleoenvironmental changes recorded in terrestrial sediments of the Paleocene-E0cene boundary (Normandy, France). Palaeogeography, Palaeoclimatology, Palaeoecology, 2013, vol. 376, pp. 184-199.

17. Guo P., Liu C., Huang L., Yu M., Wang P., Zhang G. Palaeohydrological evolution of the late Cenozoic saline lake in the Qaidam Basin, NE Tibetan Plateau: Tectonic vs. climatic control. Global and Planetary Change, 2018, vol. 165, pp. 44-61.

18. Harrington G.A., Gardner W.P., Smerdon B.D., Hendry M.J. Palaeohydrogeological insights from natural tracer profiles in aquitard porewater, Great Artesian Basin, Australia. Water Resources Research, 2013, vol. 49, Iss. 7, pp. 4054-4070.

19. Hendry M.J., Barbour S.L., Novakowski K., Wassenaar L.I. Paleohydrogeology of the Cretaceous sediments of the Williston Basin using stable isotopes of water. Water Resources Research, 2013, vol. 49 , pp. 4580-4592.

20. Hengstum P.J., Reinhardt E.G., Beddows P.A., Gabriel J.J. Linkages between Holocene paleoclimate and paleohydrogeology preserved in a Yucatan underwater cave. Quaternary Science Reviews, 2010, no. 29, pp. 2788-2798.
21. Hill C.L., Schild R. Paleohydrology and paleoenvironments at Bir Sahara: Pleistocene lithostratigraphy and sedimentology in the southern Egyptian Sahara. Journal of African Earth Sciences, 2017, vol. 136, pp. 201-215.

22. Ilani S., Rosenthal E., Kronfeld J., Flexer A. Epigenetic dolomitization and iron mineralization along faults and their possible relation to the paleohydrology of southern Israel. Appl Geochem, 1988, no. 3, pp. 487-498.

23. Jensen G.K.S., Rostron B.J., Duke M.J.M., Holmden C. Bromine and stable isotopic profiles of formation waters from potash mine-shafts, Saskatchewan, Canada. Journal of Geochemical Exploration, 2006, no. 89, pp. 170-173.

24. Karim A., Hanley J.J., Pe-Piper G., Piper D.J.W. Paleohydrogeological and thermal events recorded by fluid inclusions and stable isotopes of diagenetic minerals in Lower Cretaceous sandstones, offshore Nova Scotia, Canada. AAPG Bulletin, 2012, Iss. 6 , pp. 1147-1169.

25. Khan Z.A., Tewari R.C. Paleochannel and paleohydrology of a Middle Siwalik (Pliocene) fluvial system, northern India. Journal of Earth System Science, 2011, vol. 120, Iss. 3, pp. 531-543.

26. Beaudoin N., Bellahsen N., Lacombe 0., Emmanuel L. Fracturecontrolled paleohydrogeology in a basement-cored, fault-related fold: Sheep Mountain Anticline, Wyoming, United States. Geochem. Geophys. Geosyst., 2011, vol. 12, no. 6, no. Q06011.

27. Kraemer T.F., Wood W.W., Sanford W.E. Distinguishing seawater from geologic brine in saline coastal groundwater using radium-226; an example from the Sabkha of the UAE. Chemical Geo$\log y, 2014$, no. 371, pp. 1-8.

28. Kraus M.J., McInerney F.A., Wing S.L., Secord R., Baczynski A.A., Bloch J.I. Paleohydrologic response to continental warming during the Paleocene-Eocene Thermal Maximum, Bighorn Basin, Wyoming. Palaeogeography, Palaeoclimatology, Palaeoecology, 2013, vol. 370, pp. 196-208.

29. Li Y., Wang Y., Deng A. Paleoclimate record and paleohydrogeological analysis of travertine from the Niangziguan Karst Springs, northern China. Science in China, 2001, vol. 44, pp. 114-118.

30. Marchegiano M., Francke A., Gliozzi E., Wagner B., Ariztegui D. High-resolution palaeohydrological reconstruction of central Italy during the Holocene. Holocene, 2019, vol. 29 (3), pp. 481-492.

31. Mather C.C., Skrzypek G., Dogramaci S., Grierson P.F. Paleoenvironmental and paleohydrochemical conditions of dolomite formation within a saline wetland in arid northwest Australia. Quaternary Science Reviews, 2018, vol. 185, pp. 172-188.

32. Milodowski A.E., Bath A., Norris S. Palaeohydrogeology using geochemical, isotopic and mineralogical analyses: Salinity and redox evolution in a deep groundwater system through Quaternary glacial cycles. Applied Geochemistry, 2018, vol. 97, pp. 40-60.

33. Musgrove M., Banner J.L., Mack L.E., Combs D.M., James E.W., Cheng H., Edwards R.L. Geochronology of late Pleistocene to Holocene speleothems from central Texas: implications for regional paleoclimate. Geol. Soc. Am. Bull, 2001, no. 113, pp. 1532-1543.

34. Möller P., Rosenthal E., Geyer S., Flexer A. Chemical evolution of saline waters in the Jordan-Dead Sea transform and in adjoining areas. Int J Earth Sci (Geol Rundsch), 2007, no. 96, pp. 541-566.

35. Neymark L.A., Amelin Y.V., Paces J.B., Peterman Z.E. U-Pb ages of secondary silica at Yucca Mountain, Nevada: implications for the paleohydrology of the unsaturated zone. Appl. Geochem, 2002, no. 17, pp. 709-734.

36. Ortega C., Vargas G., Rutllant J.A., Jackson D., Méndez C. Major hydrological regime change along the semiarid western coast of South America during the early Holocene. Quaternary Research (United States), 2012, vol. 78, Iss. 3, pp. 513-527.

37. Paces J.B., Neymark L.A., Whelan J.F., Wooden J.L., Lund S.P., Marshall B.D. Limited hydrologic response to Pleistocene climate change in deep vadose zones - Yucca Mountain, Nevada. Earth and Planetary Science Letters, 2010, no. 300, pp. 287-298. 
38. Paces J.B., Whelan J.F. The paleohydrology of unsaturated and saturated zones at Yucca Mountain, Nevada, and vicinity. Memo ir of the Geological Society of America, 2012, vol. 209, pp. 219-276.

39. Pagel M., Bonifacie M., Schneider D.A., Gautheron C., Brigaud B., Calmels D., Cros A., SaintBezar B., Landrein P., Sutcliffe C., Davis D., Chaduteau C. Improving paleohydrological and diagenetic reconstructions in calcite veins and breccia of a sedimentary basin by combining $\Delta 47$ temperature, $\delta 180$ water and U-Pb age. Chemical Geology, 2018, vol. 481, pp. 1-17.

40. Quade J., Forester R.M., Whelan J.F. Late Quaternary paleohydrologic and paleotemperature change in southern Nevada. Paleoenvironments and Paleohydrology of the Mojave and Southern Great Basin Deserts: Geol. Soc. of Amer. Spec. Paper, 2003, no. 368 , pp. $165-188$.

41. Rosenthal E., Flexer A., Möller P. The paleoenvironment and the evolution of brines in the Jordan-Dead Sea transform and in adjoining areas. Int J Earth Sci, 2006, no. 95, pp. 725-740.

42. Rosenthal E., Jones B.F., Weinberger G. The chemical evolution of Kurnub Group paleowater in the Sinai-Negev province - a mass balance approach. Appl. Geochem, 1998, no. 27, pp. 3-17.

43. Ross J.B., Ludvigson G.A., M?ller A., Gonzalez L.A., Walker J.D. Stable isotope paleohydrology and chemostratigraphy of the Albian Wayan Formation from the wedge-top depozone, North American Western Interior Basin. Science China Earth Sciences, 2017, vol. 60, Iss. 1, pp. 44-57.

44. Sadofsky S.J., Bebout G.E. Field and isotopic evidence for fluid mobility in the franciscan complex: forearc paleohydrogeology to depths of 30 kilometers. International Geology Review, 2004, vol. 46 , no. 12, pp. 1053-1088.

45. Swenson J.B., Person M., Raffensperger J.P., Cannon W.F., Woodruff L.G., Berndt M.E. A hydrogeologic model of stratiform copper mineralization in the Midcontinent Rift Sestem, Northern Michigan, USA. Geofluids, 2004, no. 4, pp. 1-22.

46. Veizer J., Prokoph A. Temperatures and oxygen isotopic composition of Phanerozoic oceans. Earth-Science Reviews, 2015, no. 146 , pp. 92-104.

47. Wallin B, Peterman Z. Calcite fracture fillings as indicators of paleohydrology at Laxemar at the Äspö Hard Rock Laboratory, southern Sweden. Appl Geochem, 1999, no. 14, pp. 953-962.

48. Walvoord M.A., Stonestrom D.A., Andraski B.J., Striegl R.G. Constraining the inferred paleohydrologic evolution of a deep unsaturated zone in the Amargosa Desert. Vadose Zone J, 2004, no. 3 , pp. 502-512.

49. Yousif M., Henselowsky F., Bubenzer 0. Palaeohydrology and its impact on groundwater in arid environments: Gebel Duwi and its vicinities, Eastern Desert, Egypt. Catena, 2018, vol. 171, pp. 29-43.

50. Zak K., Kostak M., Man 0., Zakharov V.A., Rogov M.A., Pruner P., Rohovec J., Dzyuba 0.S., Mazuch M. Comprasion of carbonate $\mathrm{C}$ and $\mathrm{O}$ stable isotope records across the Jurassic/Cretaceous boundary in the Tethyan and Boreal Realms. Palaeogeo graphy, Paleoclimatology, Palaeoecology, 2011, no. 299, pp. $83-96$.

51. Sadykova Ya.V., Novikov D.A., Chernykh A.V., Dultsev F.F. Paleogidrogeokhimiya verkhneyurskikh otlozheniy arkticheskikh rayonov Zapadnoy Sibiri [Paleohydrogeochemistry of the Upper Jurassic deposits of the Arctic regions of Western Siberia]. Podzemnye vody Vostoka Rossii. Materialy Vserossiyskogo soveshchaniya po podzemnym vodam Vostoka Rossii (XXII Soveshchanie po podzemnym vodam Sibiri i Dalnego Vostoka s mezhdunarodnym uchastiyem) [Groundwaters of Eastern Russia. Materials of the All-Russian Conference on Groundwaters of Eastern Russia (XXII Meeting of Groundwaters of Siberia and the Far East with international participation)]. Novosibirsk, IPGG SB RAS, 2018. pp. 412-417.

52. Novikov D.A., Chernykh A.V., Dultsev F.F. Paleohydrogeochemistry of the Upper Jurassic Deposits of the Arctic Regions of the
West Siberian Megabasin. Journal of Physics: Conference Series, 2019, vol. 1172 (1), no. 012094.

53. Kontorovich A.E., Nesterov I.I., Salmanov F.K. Surkov V.S., Trofimuk A.A., Ervye Yu.G. Geologiya nefti i gaza Zapadnoy Sibiri [Geology of oil and gas in Western Siberia]. Moscow, Nedra Publ., 1975. 680 p.

54. Kontorovich A.E. Ways of development of oil and gas resources of the Russian sector of the Arctic. Bulletin of the Russian Academy of Sciences, 2015, vol. 85, no. 5-6, pp. 420-430. In Rus.

55. Kartsev A.A., Abukova L.A., Abramova 0.P. Slovar po neftegazovoy gidrogeologii [Dictionary of oil and gas hydrogeology]. Moscow, GEOS publ., 2015. 304 p.

56. Kontorovich A.E., Kontorovich V.A., Ryzhkova S.V., Shurygin B.N., Vakulenko L.G., Gaideburova E.A., Danilova V.P., Kazanenkov V.A., Kim N.S., Kostyreva E.A., Moskvin V.I., Yan P.A. Jurassic paleogeography of the West Siberian sedimentary basin. Russian Geology and Geophysics, 2013, vol. 54, no. 8, pp. 747-779.

57. Kontorovich A.E., Ershov S.V., Kazanenkov V.A., Karogodin Y., Kontorovich V.A., Lebedeva N.K., Nikitenko B.L., Popova N.I., Shurygin B.N. Cretaceous paleogeography of the West Siberian sedimentary basin. Russian Geology and Geophysics, 2014, vol. 55, no. 5-6, pp. 582-609.

58. Shvartsev S.L., Novikov D.A. The nature of vertical hydrogeochemical zoning of petroleum deposits (exemplified by the $\mathrm{Na}$ dym-Taz interfluve, West Siberia). Geologiya $i$ geofizika, 2004, vol. 45, no. 8, pp. 1008-1020.

59. Novikov D.A., Lepokurov A.V. Hydrogeological conditions of petroleum potential deposits on the structures in the southern part of Yamalo-Karskoye depression. Geologiya nefti $i$ gaza, 2005, no. 5, pp. 24-33.

60. Novikov D.A. Hydrogeological conditions for the presence of oil and gas in the western segment of the Yenisei-Khatanga regional trough. Geodynamics and Tectonophysics, 2017, vol. 8, no. 4, pp. 881-901.

61. Kokh A.A., Novikov D.A. Hydrodynamic conditions and vertical hydrogeochemical zonality of groundwater in the Western Khatanga Artesian Basin. Water Resources, 2014, vol. 41, no. 4, pp. 396-405.

62. Novikov D.A., Sukhorukova A.F. Hydrogeology of petroleum deposits in the northwestern margin of the West Siberian Artesian Basin. Arabian Journal of Geosciences, 2015, vol. 8, no. 10, pp. 8703-8719.

63. Novikov D.A., Vakulenko L.G., Yan P.A. Lateral Zoning of Groundwater Chemistry and Authigenic Mineralogy in the Oxfordian Regional Reservoir of the Nadym-Taz Interfluve. Russian Geology and Geophysics, 2019, vol. 60, no. 6, pp. 662-674.

64. Novikov D.A. Chemical equilibrium of groundwater with minerals of the host rocks in Upper Jurassic sediments (Arctic regions of Western Siberia). E3S Web of Conferences, 2019, vol. 98, no. 01037.

65. Novikov D.A. Genetic classification of subsurface waters and brines of Arctic regions of Siberia. IOP Conference Series: Earth and Environmental Science, 2018, vol. 193 (1), no. no. 012049.

66. Shurygin B.N., Nikitenko B.L., Devyatov V.P., Ilina V.I., Meledina S.V., Gaydeburova Ye.A., Dzyuba 0.S., Kazakov A.M., Mogucheva N.K. Stratigrafiya neftegazonosnykh basseynov Sibiri. Yurskaya sistema [Stratigraphy of Siberian oil and gas basins. Jurassic system]. Novosibirsk, SB RAS Publ. Branch «GEO», 2000. $480 \mathrm{p}$.

67. Burst J.F. Diagenesis of Gulf Coast Clayey Sediments and Its Possible Relation to Petroleum Migration. AAPG Bulletin, 1969, vol. 53 , no. 1, pp. 73-93.

68. Perry E.A., Jr., Hower J. Late-stage dehydration in deeply buried politic sediments. AAPG Bulletin, 1972, vol. 56, no. 10, pp. 2013-2021.

69. Shaw D.B., Weaver C.E. The mineralogical composition of shales. Journal of Sediment Research, 1965, vol. 35, no. 1, pp. 213-222. 
70. Novikov D.A. Oil and gas fields exploration in the Jurassic-Cretaceous deposits of Yamal Peninsula based on the water-gas equilibrium. Oil Industry, 2018, vol. 4, pp. 16-21.

71. Novikov D.A. Role of Elisional Water Exchange in the Hydrodynamic Field Formation in the Yamal-Kara Depression. Lithology and Mineral Resources, 2019, vol. 54 (3), pp. 236-247.

72. Novikov D.A., Dultsev F.F., Chernykh A.V. Abnormally high formation pressures in jurassic-cretaceous reservoirs of Arctic regions of Western Siberia. IOP Conference Series: Earth and Environmental Science, 2018, vol. 193 (1), no. 012050.
73. Shvartsev S.L. Interaction in the water-rock system as a new basis for the development of hydrogeology. Russian Journal of $\mathrm{Pa}$ cific Geology, 2008, vol. 27, no. 6, pp. 465-475.

74. Novikov D.A. Hydrogeochemistry of the Arctic areas of Siberian petroleum basins. Petroleum Exploration and Development, 2017, vol. 44, no. 5, pp. 780-788.

Received: 25 January 2019.

\section{Information about the authors}

Dmitry A. Novikov, Cand. Sc., head of the laboratory, Trofimuk Institute of Petroleum Geology and Geophysics of Siberian Branch of Russian Academy of Sciences; assistant professor, Novosibirsk State University.

Anatoliy V. Chernykh, junior researcher, Trofimuk Institute of Petroleum Geology and Geophysics of Siberian Branch of Russian Academy of Sciences.

Yana V. Sadykova, Cand. Sc., senior researcher, Trofimuk Institute of Petroleum Geology and Geophysics of Siberian Branch of Russian Academy of Sciences.

Fedor F. Dultsev, junior researcher, Trofimuk Institute of Petroleum Geology and Geophysics of Siberian Branch of Russian Academy of Sciences.

Vasilina A. Khilko, junior researcher, Trofimuk Institute of Petroleum Geology and Geophysics of Siberian Branch of Russian Academy of Sciences.

Irina I. Yurchik, junior researcher, Trofimuk Institute of Petroleum Geology and Geophysics of Siberian Branch of Russian Academy of Sciences. 